\title{
EU Competition Policy: Some Real Case Applications*
}

\author{
João Tovar Jalles†
}

October 2007

\begin{abstract}
European Union Antitrust Laws have been successfully applied to anti-competitive behaviour, which can take place abroad, but have an effect within the EU. Under Antitrust Laws, not only abuse of dominant position practices but also mergers that restrain competition are regarded as illegal and subject to severe remedies.

This paper accesses both Microsoft-WMP and Volvo-Scania cases in the light of the EU Competition Policy and identifies the circumstances involved, final decisions made as well as the suggested remedies and the consequences from the consumers' perspective. The issues considered are per se controversial and these are clear examples of the long path to go through, in order to make the competition law regime uniformly applicable in all member states.

The lack of international consensus on competition law and enforcement requires huge efforts in co-operation between countries and organisations, because in combination with economic liberalisation, nations have come to recognise competition as a powerful instrument for stimulating innovation and economic growth. This paper focus on the past, i.e., already assessed anticompetitive cases; the present the current EU Competition Policy rules - and finally on the future of Antitrust jurisdiction, in which part I will briefly describe the major actual concerns in the long course towards a common and homogeneously valid system of International Competition Policy.
\end{abstract}

JEL codes: L41,L43, L44, L51

KEYWORDS: Antitrust, Dominant Position, Tying, Microsoft-WMP, EU Competition Policy, Volvo-Scania, Horizontal Merger

\footnotetext{
* The usual disclaimer applies, i.e, all errors are mine alone.

† School of Economics, New University of Lisbon·Email: j.jalles@fe.unl.pt
} 


\section{TABLE OF CONTENTS}

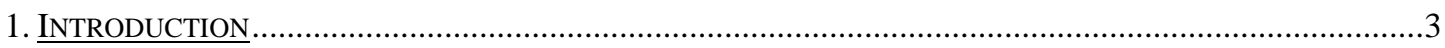

2. A General OVERVIEW OF THE EU Competition Policy .................................................................

2.1 Anti-Trust Policy - Abuses of a Dominant Market Position...................................................

2.2 European Merger Policy ..............................................................................................

3. The Internationalization of Antitrust Policy - A Global Competition Policy and the

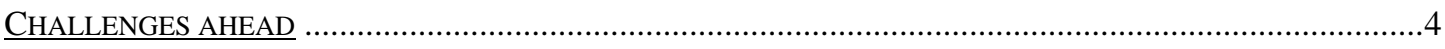

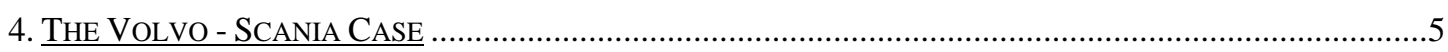

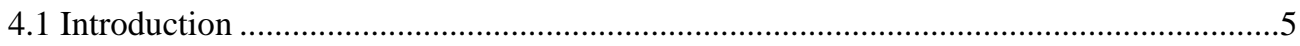

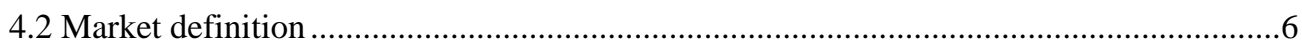

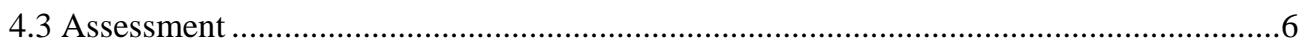

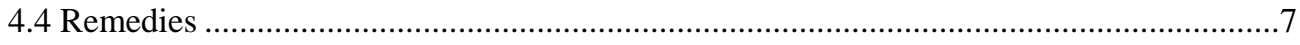

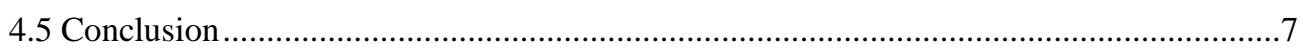

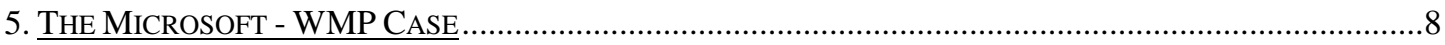

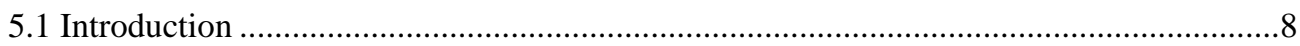

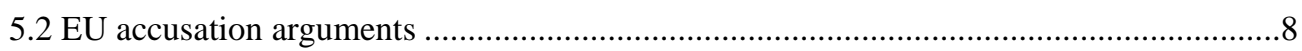

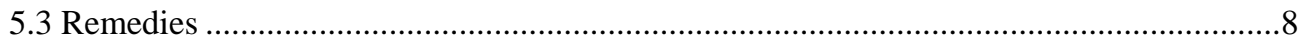

5.4 Tying: the important issue about the EU Commision VS Microsoft Case ........................9

5.5 The everlasting problem: Monopoly and Microsoft ...........................................................

5.6 The Model Windows - WMP.....................................................................................10

\# 5.6.1 Software pricing and Market Segmentation ..............................................13

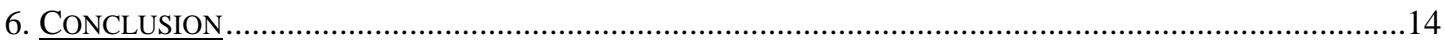

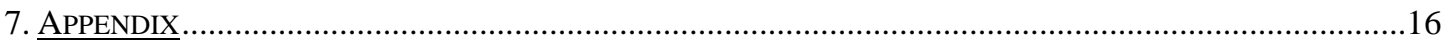

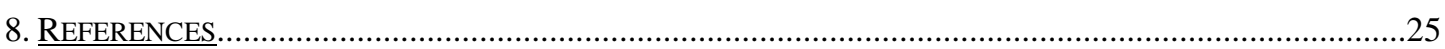

TABle OF ABbreViations:

$\begin{array}{ll}\text { CFI } & \text { Court of First Instance } \\ \text { DG } & \text { Directorate General } \\ \text { EC } & \text { European Commission } \\ \text { EEA } & \text { European Economic Area } \\ \text { EU } & \text { European Union } \\ \text { ICN } & \text { International Competition Network } \\ \text { OECD } & \text { Organization for Economic Cooperation and Development } \\ \text { OS } & \text { Operating System } \\ \text { PC } & \text { Personal Computer } \\ \text { UNCTAD } & \text { United Nations Conference on Trade and Development } \\ \text { US/USA } & \text { United States of America } \\ \text { WMP } & \text { Windows Media layer } \\ \text { WTO } & \text { World Trade Organization }\end{array}$




\section{Introduction}

The wealth of a nation consists of all goods that fulfil the consumer's wants, therefore increasing wealth means expanding the quantity, quality and variety of consumer goods. The idea of a free and decentralized market with a socially optimal allocation has been alive among economists, since the time of Adam Smith's “indivisible hand". However, we must notice that real market conditions are characterized by market structures between perfect competition and monopoly. Hence, conditions dominated by imperfect competition, asymmetric information or external effects make competitive equilibria socially inefficient - typical in nowadays industries in the new economy.

The problem is that the above analysis is a static one vis-à-vis dynamic models that take into account that efforts to become a monopoly and enjoy high prices are the engine of the competitive innovation process, although such efforts might be wasteful. Monopoly profits are also an important signalling tool that stimulates competition, as the higher the monopolist price, the higher the incentive of rival firms to take part in these profits by undercutting the monopolist. Thus, economic theory has shown that monopoly pricing is not always inefficient, and that is why I will analyse/model the Microsoft-WMP case as an example of a controversial issue among economists.

Monopoly pricing is a de facto major concern of antitrust: if firms seek to raise their profits through merger, they must attain governmental/EU approval; when a firm abuses of its dominant position by performing anti-competitive strategies, such actions are not only unenforceable, but also subject to criminal charges in EU jurisdiction. For the past years, the Commission has focused primarily on facilitating market entry rather than on regulating "unfair" prices per se (emphasis in thus shifting from "fair" competition into free competition). Monopoly pricing regulation is thus a microcosm of competition policy. ${ }^{2}$ Market power is the main concern of the international antitrust policy. ${ }^{3}$ From a public policy point of view, market power has negative and positive implications, which often makes antitrust policy ambiguous if not paradoxical. The negative implications of market power are, inter alia: wealth transfer from the consumers to the firm; loss in efficiency; and rent-seeking. ${ }^{4}$ The most positive implication is the incentive to innovate, thus it leads to dynamic efficiency (i.e. technological progress) with respect to certain goods. It follows that increasing market power is a necessary but not sufficient condition of every (core) antitrust offence. There is no question that competition is an issue of primary importance in open market economy - it leads to price reduction, innovation, better efficiency and wider choice for consumers. The definition of the relevant market is, $a b$ initio, one of the most important, if not the decisive, problem concerning antitrust law ${ }^{5}$.

The proposed merger between Volvo and Scania was notified to the European Commission on 22 September $19999^{6}$. A Commission Decision on 15 March 2000 declared the merger incompatible with the Common Market and the functioning of the EEA, based on the definition of the relevant market, inter alia. In March 2004, the EC held that Microsoft used its Windows OS to unfairly leverage its "overly

\footnotetext{
2 See Michal S. Gal, Monopoly pricing as an antitrust offence in the US and EC: Two systems of belief about monopoly?, forthcoming, Antitrust Bulletin (summer 2004).

3 See Dabbah, Maher M., The Internationalization of Antitrust Policy, Cambridge University Press, UK, First published 2003, p. 46-58.

${ }^{4}$ See Overgaard, Baltzer, Notes on antitrust policy and regulation in the EU and beyond, University of Aarhus, May 26, 2003.

${ }^{5}$ See Baker, Donald I., Market Definition in Transnational J oint-Ventures, Mergers and Monopolization, p. 118.

${ }^{6}$ See Case No COMP/M. 1672 European Commission.
} 
dominant position"7 in the PC operating systems market. By tying WMP to its OS, the EC said the company is unfairly harming its competitors’ products. The imposed remedy required Microsoft offer its Windows OS without WMP and also to disclose its proprietary technical information so rivals can build products that are compatible with Microsoft's OS. And, finally, the EC imposed its largest fine everover EUR 497 million.

\section{A General Overview of the EU Competition Policy ${ }^{8}$}

The aim of EU competition policy is, per definitionem, to promote competition and create a single market, which goes beyond national borders as well as to promote the process of economic integration $^{9}$. Competition policy is a mean to ensure wider consumer choice, technological innovation and effective price competition. There are four pillars of EU competition policy: antitrust \& cartels, market liberalization, state aid control, and abuse of dominance and merger control ${ }^{10}$. Due to the cases analysed in this paper I will refer only to the first and fourth points.

Anticompetitive practices are per definitionem strategies intentionally designed to limit the degree of competition inside a market. Such actions can be taken by one firm in isolation or a number of firms engaged in explicit or implicit collusion. Examples of anticompetitive practices are, inter alia: predatory pricing, vertical restraint in the market, creation of artificial barriers to entry, and collusive practices. ${ }^{11}$ Practices are not prohibited if the respective agreements "contribute to improving the production or distribution of goods or to promoting technical progress in the market”. ${ }^{12}$ In a free and decentralized market, business is a competitive game. Sometimes, companies may be tempted to avoid competing with each other and try to set their own rules of the game. The European Commission, per se, acts as the referee to ensure that all companies play by the same rules. ${ }^{13}$

\subsection{Anti-Trust Policy - Abuses of a Dominant Market Position}

Antitrust is the study of competition. It is a bundle of laws that seek to ensure competitive markets through the interaction of sellers and buyers in the dynamic process of exchange. Antitrust law is centered on a primary principle that society is better off if markets behave competitively. Figure 1 present number of new antitrust cases opened in years 1993-2002. Even if counting only newly opened cases, it is clearly visible that the DG Competition of European Commission has to engage massive work.

A firm holds a dominant position if its economic power enables it to operate within the market without taking account of the reaction of its competitors or of intermediate or final consumers. Holding a dominant position is not wrong in itself if it is the result of the firm's own effectiveness and competitiveness against other businesses. But if the firm exploits this power to stifle competition, this is deemed to be an anti-competitive practice which constitutes abuse. A good recent example of this was the

\footnotetext{
${ }^{7}$ See Case No COMP/C-3/37.792 European Commission.

8 See Commission: DG-Competition: http://europa.eu.int/comm/competition/index en.html.

${ }^{9}$ See Jonczek, Joanna, Competitive Market - Antitrust dimension of competition policy in the EU, YouRec Conference Paper, February 2004.

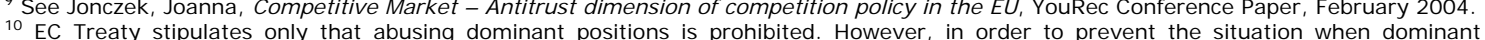
10 EC Treaty stipulates only that abusing dominant positions is prohibited. However, in order to prevent the situation when dominant
position is achieved through mergers and acquisitions, the Merger Regulation had been adopted; see: Council Regulation (EEC) No 4064/89 of 21 December 1989 on the control of concentrations between undertakings and amendments.

${ }^{11}$ See generally Goyder, D G, EC Competition Law, Oxford European Community Law Series, Clarendon Press.

12 See Article 81 of the EC Treaty.

${ }^{13}$ See Dabbah, Maher M., The Internationalization of Antitrust Policy, Cambridge University Press, United Kingdom, First published 2003, p. 86-95.
} 
investigation by the EU Commission into the alleged abuse of market power by Microsoft. Microsoft was accused by the Commission of continuing to abuse its monopoly in the software market. The investigators alleged that Microsoft bundled Media Player with Windows, unfairly damaging rival programs such as Real Networks’ RealPlayer and Apple Computer’s QuickTime.

\subsection{European Merger Policy (Figure 2)}

The main issue about these cases is whether a proposed merger or takeover is thought to lead to a substantial lessening of competitive environment in the market and risks leading to a level of market concentration (calculations theoretically based on Lerner and Bain Indexes) when collusive behaviour might become a reality.

Often a merger is allowed to progress without any intervention by the competition authorities when the economic benefits of allowing the integration to take place are significantly greater than the potential costs. Here are some of the main justifications for approving a merger between two businesses: efficiency arguments ${ }^{14}$, the role of the capital markets, market contestability arguments, the capital investment argument, the globalization argument, and mergers as a means of enhancing economic integration within the EU. As counter-arguments we have: monopoly power, mixed evidence on benefits of mergers, imperfections in capital markets, and employment effects.

\section{The Internationalization of Antitrust Policy - A Global Competition Policy and the Challenges ahead}

The internationalization of antitrust policy is a topic of great contemporary significance and debate. With increasing globalisation of trade ${ }^{15}$, more and more companies, mergers and cartels are international. Consequently, the activities of companies based outside the EU may affect competition within the EEA. This has made international cooperation on competition policy essential. ${ }^{16}$ Any company whose activities affect the EU market is subject to European competition law. (e.g. the European Commission can intervene where a merger affects competition in the EU, whether or not the merging companies are based within the EU).

Nowadays, almost all national authorities are members of forums such as the ICN, which is an informal, worldwide network of competition authorities. International business community leaders should take immediate responsibility to take action and reform, given the serious and increasing marketplace costs imposed by multiple and divergent antitrust regimes ${ }^{17}$. Strong competition and consumer protection policy is crucial to maintaining a marketplace that benefits consumers and that position EU firms to compete fiercely abroad.

\footnotetext{
${ }^{14}$ See Walters, Stephen J. K., Enterprise, Government and the public, McGraw Hill, Inc, 1993, p. 39.

15 See generally Schaub, Alexander, International Co-operation in Antitrust Matters: Making the point in the wake of the Boeing/MDD Proceedings, EC Competition Policy Newsletter, Feb. 1998 (No. 1), at 2, available at http://europa.eu.int

${ }_{16}$ See Wakil, Omar K. et al., Antitrust Report: Canada and the European Union enter into a new era of antitrust enforcement cooperation, Lexis Publishing, February 2000.

17 See James, Charles A., International Antitrust in the $21^{\text {st }}$ Century: Cooperation and Convergence, US Department of Justice, Antitrust Division, 2001.
} 
Regarding cooperation in this domain we can have bilateral agreements, as well as multilateral contact. $^{18}$ Multilateral discussions between enforcement agencies occur on a number of fronts, primarily under the auspices of the OECD ${ }^{19}$ and WTO, although other agencies, such as UNCTAD, also play a vital role.

The major obstacles existing in Member State laws: absence of transparent statutory basis for bringing EC competition law based damages actions; lack of designation of limited number of specialized competition courts; lack of binding effect on national courts of cartel authorities decisions; uncertainties as to calculation of damages; no punitive damages accepted - lengthy proceedings - costs and fees not entirely recoverable in practice; no contingency fees admitted. Suggestions to assist private enforcement: develop access to courts; decrease legal uncertainties; improve degree of expertise by restricting number of competent courts; facilitate proof of elements of liability; reduce financial costs and length of proceedings; improve remedies’ information. ${ }^{20}$

Thus, in the presence of international trade, competition policies implemented on a national level will mean that countries impose substantial external effects on each other. As a result, increased international economic integration enhances the benefits from international coordination of competition policies. A number of problems arise form centralizing competition policy to a supranational institution like the European Commission, as exemplified by the recent blocked merger plan between the two Swedish motor-vehicle makers, Volvo and Scania.

The Volvo-Scania case brought the question of whether small countries, like the Nordic ones, are at a disadvantage ${ }^{21}$ if the Commission's definition of market dominance automatically refers to fairly small and segmented national markets rather than to the European market in a larger sense. This in turn, leads to the small countries concern of losing even more capital and investment to larger and more competitive countries. ${ }^{22}$ Reasonable merger analyses often imply that the definition of national markets often coincide with national borders. Hence, firms in small countries face tighter merger restrictions because they will quickly reach critical market shares, even though they might, in a global perspective, still be relatively small in absolute size. Proponents of this argument advocate that it is beneficial for small countries to allow mergers that potentially harm domestic consumers, because such mergers have the advantage of making domestic companies large enough to capture rents on imperfectly competitive international markets. Namely, because firms in small countries can engage in cross-border mergers these firms can acquire international competitiveness without sacrificing domestic consumer interests.

\footnotetext{
18 On September 23, 1991, the EC signed a bilateral antitrust cooperation agreement with the US, and on April 10, 1995, the European Commission and Council adopted a joint decision approving the $1991 \mathrm{EU}$-US agreement and declaring it applicable from then onwards.

19 See Revised Recommendation of the OECD Council concerning Cooperation between member countries on Anticompetitive practices affecting international trade, OECD document No C(95)130/Final (Sept. 21, 1995).

20 See Gerven, Walter van, Private enforcement of EC competition rules (provisional background paper), Joint EU Commission/IBA Conference on antitrust reform in Europe: a year in practice, Brussels, 10-11 March 2005

${ }^{21}$ See Fran Riksdag \& Departement, Nr 30, 2001 Almeberg, R, Monti, Foretagen och Konkurrensen, p.3.

${ }^{22}$ See Svenska Dagbladet, Ledare, Kommissionen Kvaddar Fusionen, 15.03.2000, p. 2.
} 


\section{The Volvo - Scania Case ${ }^{23}$}

\subsection{Introduction}

In 1999, AB Volvo, a Swedish industry, underwent a complete restructuring. Volvo’s car production, representing approximately half of the company's entire business, was sold off to the Ford Motor Co. of Detroit. Volvo's decision to sell the automobile division reflected its determination to concentrate on its trucks, buses and engines businesses. Thus, Volvo subsequently ventured onto the market, acquiring a large shareholding of Scania AB, its main Swedish competitor in the production and marketing of trucks and buses.

On August 6, 1999 AB Volvo reached an agreement with Investor AB, the then main holder of the shares in Scania AB, to acquire the control of Scania. Having in mind the EC Merger Regulation (Figure 3), Volvo notified the Commission of the plans to acquire Scania. Following the first stage investigation, which gave rise to serious concerns whether the merger was compatible with the rules and regulations of the Common Market, the Commission decided to institute the so-called "Phase 2" procedure, according to Article $6(1)(c)^{24}$ of the Merger Regulation. The investigation resulted in a Commission Decision prohibiting the proposed acquisition as incompatible with the Common Market pursuant to Article 8(3) of the Merger Regulation (14 March 2000). ${ }^{25}$ The decisive factor influencing the Commission's decision was, the determination of the relevant product and geographic market. ${ }^{26}$ (Figure 4) Volvo and Scania were relatively equal in terms of market share of the truck and bus markets, and had been the main competitors on the Nordic market for a while, building up their strong positions in the home market. Other manufacturers of trucks and buses were small compared to Volvo and Scania on the Nordic markets (particularly on the Swedish one). Both Volvo and Scania had created their distinctive images in heavy and technologically advanced vehicles and were primarily active in the top, most expensive segments of the markets of trucks and buses. The merger between Volvo and Scania would have made the company the largest truck company in Europe (Figure 5).

\subsection{Market definition}

The analysis of the relevant product market is simple. The truck market is classified in three categories: light duty trucks (less than 6 tons), medium duty trucks (5-16 tons) and heavy duty trucks (more than 16 tons). ${ }^{27}$ The heavy truck market is then subdivided into two segments: Rigid trucks and tractor trucks (Figure 6). While it is known that rigids and tractors may not be fully substitutable, the final conclusion is that the category of heavy trucks constitutes the single relevant market. Light and medium duty trucks are thus not included.

The analysis of the relevant geographic market is more detailed ${ }^{28}$. As stated above, the failure of Volvo's notification was largely due to the Commission's restricted definition of the relevant geographic

\footnotetext{
${ }^{23}$ Case No COMP/M. 1672 - Volvo/Scania Regulation (EEC) No 4064/89 Merger Procedure Article 8(3) Date: 15/03/2000 europa.eu.int/comm/competition/ mergers/cases/decisions/m1672 en. pdf

${ }_{24}$ Regulation $4064 / 89$ on the Control of Concentrations Between Undertakings.

25 See Hemmingsson, Elisabeth, The Volvo/Scania Merger: An Analysis of the EC Merger Process, Gothenburg School of Economics and Commercial Law-Faculty of Law, Masters Thesis in Law, Spring 2002-06-21 http://www.handels.gu.se/epc/archive/00003259/01/200262.pdf

${ }_{26}$ See Monti, M, Market Definition as a Cornerstone of EU Competition Policy, Speech/01/439, 5 October 2001

27 OJ, L143, 29/05/2001 P. 0074 - 0132, The Commission Decision, Case No COMP/M. 1672 Volvo/Scania, at paras 13-15

28 See Hemmingsson, Elisabeth, The Volvo/Scania Merger: An Analysis of the EC Merger Process, Gothenburg School of Economics and

Commercial Law-Faculty of Law, Masters Thesis in Law, Spring 2002-06-21, p.39-40, 42-47.
} 
market as the national market of each of the Nordic countries, Ireland and the UK (different from Volvo and Sweden's contention that the relevant geographic market was EEA-wide). While, the new VolvoScania's share of the western European market would have been around $30 \%$, its share of the market of the Nordic countries, particularly Sweden, was estimated at an average of $2 / 3$ and $90 \%$, respectively (Figure 7 and 8). In its notification, Volvo relied on a series of non-price factors meant to support the argument that the relevant geographic market was EEA-wide, namely (a) the emergence of large, private, trans-border purchasers, who have knowledge of prices and competitive conditions in other Member States when negotiating with distributors of trucks; (b) the emergence of dual sourcing, which ensures independence of customers from any single manufacturer; (c) product standardization, which resulted in the fact that the same basic truck can be sold and used throughout Europe; and (d) the absence of entry barriers for nondomestic producers. However, the Commission counterbalanced the above arguments, with the following: First, there are substantial price and markup differences across countries - different price-elasticities of demand (Figure 9). Second, the models and technical configurations differ considerably, because of local consumer preferences and national technical requirements. Third, the selective and exclusive distribution system links the sales and after-sales services. The importance of profits from after-sales service may therefore induce dealers to charge higher prices to foreign customers. Finally, there are large variations in market shares across countries.

\subsection{Assessment}

The Commission Decision explicitly describes its methodology for assessing the creation or strengthening of a dominant position (ex-officio). According to Article 2(3) of the Merger Regulation, a concentration that creates or strengthens a dominant position as a result of which effective competition would be impeded in the Common Market or in a substantial part of it, shall be declared incompatible with the Common Market. It used traditional market power variables, i.e., market shares, supplemented by qualitative factors such as customer purchasing power and the likelihood of entry. The investigation is limited to the five countries where the creation of a dominant is found (Sweden, Norway, Finland and Ireland), or where this is found to be likely (Denmark). For each of the five countries analyzed, the Commission took the market shares as the starting point of the assessment. Figure 7 gathers the market shares of the seven truck manufacturers. The table shows that the joint market share of Volvo and Scania is the largest in precisely the five countries where dominance is found (in the 49-91 percentile). This reveals that the Decision attached a high weight to the merging firms' joint market share in assessing dominance. In its market share analysis the Commission also underlined that the merging firms' joint market share had remained stable, and showed no tendency to decline. Finally, the Commission pointed out the large difference between the joint market share of the merging parties and the market share of the largest remaining competitor in most of the five countries.

The Commission supplemented its market share analysis with qualitative factors. First, the extent of brand loyalty and the customer structure was considered (the Commission found indicators of considerable brand loyalty and of a dispersed customer structure). The Commission concluded that there was little customer purchasing power to compensate for the increased market power by the merging 
firms. Second, the possibility of entry was studied. The Commission claimed that competing undertakings faced substantial barriers of entry into the relevant markets, especially in Sweden, inter alia, due to the following: (a) the Nordic markets were small and sparsely populated; (b) the existence in Sweden by legislation of the special "cab crash test", a crash safety test for truck-driver seats functioning as a technical barrier to trade and (c) the need to establish a high service network level. With all these conditions, the Commission found that it was highly improbable that sufficiently effective competition would remain in the examined countries after the merger of Volvo and Scania, even though some efficiency reasons presented by Volvo. (Figure 10)

\subsection{Remedies}

The commitments involved, inter alia, allowing car dealers and servicing companies full freedom to sell and service competing makes, that Volvo during a two year period would refrain from selling heavy trucks under the brand name of Scania and that certain of Scania's bus production units would be sold off.

Moreover, both parties must not only reduce their collective market power, but also restore conditions for effective competition, which would be distorted as a result of the merger. Probably, the Commission would have accepted divestiture, which is the most preferred remedy in merger cases. News reports indicated that divestiture of Scania's bus operations and elimination of the Scania truck brand in Ireland and the Nordic states were among remedies suggested by the Commission to the parties, however, not accepted by the latter.

\subsection{Conclusion}

In view of the above, the Commission has come to the conclusion that the notified concentration was incompatible with the common market and the functioning of the EEA Agreement, since, it would create dominant positions in certain the markets, which would result in competition being significantly impeded in the common market within the meaning of Article 2(3) of the Merger Regulation and Article 57 of the EEA Agreement. ${ }^{29}$

The Volvo/Scania Decision illustrates what a decisive impact of the relevant the market definition has in competition cases such as this ${ }^{30}$. On this point, the concentration would have resembled a monopoly situation. Nordic customers would have been the most affected by an increase in prices linked to absence of competitive pressure, since they had been paying even more prior to the merger (Figure 11). One could consider three ways in which horizontal mergers might create or strengthen a dominant position as a result of which effective competition would be significantly impeded: a merger may create or strengthen a dominant position of the only large firm in an industry ("a firm with a paramount market position”); a merger may diminish the degree of competition in a concentrated market by eliminating important competitive constraints ("non-collusive oligopolies"); and a merger may create or reinforce a situation where competition is reduced by co-ordination (“increased risk of co-ordination”).(Figure 12)

\footnotetext{
29 Commission of the European Communities Press Release - 14 March 2000, Press Release Regarding Commission Prohibition of Volvo/Scania Concentration, Document No: EUK9732852

${ }^{30}$ See Handler, M., Antitrust in Transition, Volume 2, Transnational J uris Publications Inc. Ardsley-on-Hudson, New York, p.639.
} 
The specific case in hands comprises the three situations in case the merger would have been allowed to happen. In that case consumers would be worse off, as one can show with a "welfare analysis" according to different countries (Figure 13). It is easy to see that the largest fall in consumer surplus and largest increase in industry profit occurs in the Nordic countries (Sweden, Norway and Finland). When looking at the change in welfare it is worth noticing that only negative sings appear in the presented table. Now suppose that the merger would imply some kind of “cost efficiencies” (Figure 14). Even though, one could see that whatever the percentage of cost efficiency chosen, in the Nordic countries consumers would be always worse off as their loss in surplus would outweigh the profit gain by producers (VolvoScania). The overall conclusion is, then, a welfare reduction for society in the case of merger.

\section{The Microsoft - WMP Case ${ }^{31}$}

\subsection{Introduction}

In 2004, the European Commission fined Microsoft EUR 497 million for abusing its dominant position in the market for OS for PCs between 1998 and 2004. ${ }^{32}$ The European had found that Microsoft broke the European Union competition law and after a five-year investigation the EC concluded that Microsoft had carried out illegal practices "by leveraging its near monopoly in the market for PC OS onto the markets for $[. .$.$] for media players". 33$

\subsection{EU accusation arguments}

The commission's case against Microsoft is detailed in a document, known as the "Statement of Objections”. The document, accused Microsoft of behaving anti-competitively in two areas. First, the commission alleged that Microsoft was trying to extend its desktop monopoly ${ }^{34}$ into the market for workgroup servers by keeping secret the communications protocols that enable its desktop and server products communicate (rivals could not compete fairly in the market). ${ }^{35}$ Secondly, Microsoft was accused of trying to extend its monopoly into the media-player market, by bundling its WMP software into Windows $^{36}$. Rival products, did not have this advantage; nor could WMP be uninstalled. This had the effect of populating all PCs with Windows media player and distorting competition by driving content providers and applications developers to the Windows media platform. "The result is a weakening of effective competition in the market...and less innovation,” it concluded. ${ }^{37}$ This innovation problem does not lay with Microsoft but with capitalism. Both the US case and the EC ruling reveal that Microsoft has played a significant role in retarding the development of technological innovations that threaten its

\footnotetext{
${ }^{31}$ See Ayres, Ian \& Nalebuff, Barry, Going soft on Microsoft? The EU's Antitrust case and remedy, The Economist's Voice, Vol. 2, Issue 2, Art. 4, 2005.

32 The full decision is available at "Commission Decision": www.europa.eu.int/comm/competition/antitrust/cases/decisions/37792/en. pdf. See para 543.

33 Ibidem paras $473-514,541,779$

${ }^{34}$ See J ohn R. Wilke, John R. \& Mitchener, Brandon, A Global Journal Report: Microsoft Rivals Allege Antitrust In New EU Case - Group

Opens Added Front, Challenging Software Giant Over Windows XP System, Wall St. J., Feb. 11,2003, at A.1.http://www.global-trade-

law.com/Article. Antitrust\% 20(Microsoft\% 20\&\% 20EU) \% 20(WSJ \% 202.11.03). htm.

${ }^{35}$ See "Commission Decision" supra note 32 at para 779

${ }^{36}$ See supra note 32 .

${ }^{37}$ See "Commission Decision" supra note 32 at para 700
} 
dominance. A $90 \%$ market share means that applications released by Microsoft become the de facto standard, regardless they are the best tools. (Figure 15)

The argument that the efficiencies derived from incorporating WMP into Windows prevail over the anti-competitive effects was dismissed. The commission observed that the incorporation of WMP in Windows “sends signals which deter innovation”. It used new evidence from updated market shares to illustrate how Microsoft's server and media-player had advanced at the expense of rivals. But it did confirm that Microsoft was exploiting its desktop dominance in workgroup server software; and that, by “tying” WMP to Windows, it had overtaken its chief rival in the media-player market, RealNetworks ${ }^{38}$. (Figure 16) A difficult aspect of the law is that Article 82 places emphasis on the protection of competition that already exists, rather than on pursuing the introduction of new.

\subsection{Remedies}

The simplest one was a fine that reflected the "gravity and duration" of the infringement. European antitrust law allows violators to be fined as much as $10 \%$ of their annual worldwide revenues. In addition, Microsoft would be required to license its server-communications protocols to rivals on a “reasonable and non-discriminatory” basis. ${ }^{39}$ Other, Microsoft should provide information to competitors to allow them to interface with its servers ${ }^{40}$. More controversial was the remedy proposed by the commission to address the tying of WMP to Windows. It suggested two alternatives: one forcing Microsoft to "untie" the two products and produce a version of Windows without $\mathrm{WMP}^{41}$; the other a "must-carry" approach, which would require Microsoft to include its leading rivals' media-player software with every copy of Windows.

The company argued that support for the playing of audio and video was part of the core functionality of Windows. Furthermore, it pointed out that PC-makers were, entitled to install media players made by other firms together with WMP. Microsoft said that forcing Microsoft to produce a Europe-specific version of Windows without WMP would, in fact, impose an inferior product on European consumers. ${ }^{42}$ It was hard to discuss that this would be in their interests. Finally an agreement on versions of Windows without a media player took place. A Microsoft press release reported that the company has agreed to adopt the names "Windows XP Home Edition N" and "Windows XP Professional Edition N" for the versions of Windows it must offer without a media player.

\subsection{Tying: the important issue about the EU Commision VS Microsoft Case}

The Commission presents four conditions that have to be satisfied for tying to be prohibited under Article $82 .{ }^{43}$ The first condition is that the tied good and the tying good are separate products; the remaining conditions require dominance in the tied good; that no untied supply is available; and that tying forecloses competition.

\footnotetext{
${ }^{38}$ Ellis Booker, RealNetworks Exec to Senate: Microsoft Breaks our Software, Internetweek.com, (1998): www. internetwk.com/news/news0723-9.htm.

${ }^{39}$ See "Commission Decision" supra note 32 at para 1003

40 Nicholas Kulish, Nine States Argue That Microsoft Still Illegally Thwarts Competition, Wall St. J., Mar. 19, 2002, at B.3.

${ }^{41}$ See "commission Decision" supra note 32 at para 1011.

42 Ibidem para 637, Microsoft it self has used the argument of interoperability when it sells its products as a superior alternative to competition. See ibidem para 638 et sequentia.

43 Ibidem para 982.
} 
Concentrating on the first condition, there is an immediate problem of definition. As frequently mentioned by economists, all products can be thought of as "bundles" of individual components. The Commission argues that whether the tied and tying products are distinct depends on whether there exists "independent demand" for the tied product. Its argument that the tying of WMP to Windows meets the first condition for its abusive tying test then seems to rest on the observation that separate media players are available, and that there is clearly consumer demand for these players. Since the Commission has established that Microsoft is dominant in the tied product, and since no untied version of Windows was available, its test of abuse tries to evaluate to whether tying diminishes competition in the market for the supply of media players. ${ }^{44}$

Another way to address the problem of when tying should be interpreted as an abuse of a dominant position is to abandon the concept of "tying" altogether. In the Microsoft case "tying" can be re-interpreted as potential refusal to supply cases. Some argue that the use of a dominant position to achieve benefits in supplying a related market, which would not be obtainable without that dominant position, could be defined to contradict a concept of competition on the merits. In fact, the Commission's analysis is more convincing as its focuses on whether Microsoft's tying practice threatens the existence of rivalry between different media players, without being sidetracked by whether Microsoft's practices allow "competition on the merits". 45

It is not clear what the difference is between a firm that is "overwhelmingly dominant", as Microsoft was found to be in market for client PC operating systems, and a firm that is just dominant. The Commission's terminology highlights a paradox of market definition and dominance analysis. "Overwhelmingly dominant" could mean that the Commission considers Microsoft to be almost certainly dominant in the supply of client PC operating systems. In contrast, a competition authority finds a firm "dominant" when it has a market share of a little over 40 per cent, then this could mean that there is a sufficient risk that the firm is dominant, and therefore that it is appropriate to apply the obligations of Article 82 of EC competition law to that firm. Even with such an interpretation, it remains doubtful that "overwhelmingly dominant" is a useful addition to the vocabulary of competition policy.

\subsection{The everlasting problem: Monopoly and Microsoft}

Monopoly is the unavoidable outcome of the evolution of capitalist economy. (Figure 17) Not only in computer technology, but also in every major industry, the process of capitalist accumulation leads to the big capital firms driving small capital out of the market, with one or several companies eventually becoming dominant. Microsoft is the product of a social system and if Microsoft is a monopolist in this traditional economic sense, then it must be restricting its output and raising price. Contrarily, Microsoft seems to be selling too many of its products, sometimes giving them out for free.

Traditional economic theories cannot explain Microsoft behaviours and their effects on competition and market efficiency. In the digital marketplace, the fact that there is one dominant firm does not imply that the firm has monopoly market power or that the market is inefficient. Three

\footnotetext{
${ }^{44}$ AAl column for FTC: WATCH 3/04 Microsoft and the Media Player Market: There's an American Story, too, Norman Hawker, Western Michigan Universirty: www. antitrustinstitute.org/recent2/304.pdf.

${ }^{45}$ See "Commission Decision" supra note 32 at para 1027.
} 
arguments, to defend Microsoft's position as the dominant player in the computer industry, are: (1) Microsoft may have no monopoly power even when it is a de facto monopolist; (2) an efficient software market may support only one firm due to scale economies and the digital product's falling marginal cost; (3) network externalities in software tend to favour one firm over the others. ${ }^{46}$

Firstly, Microsoft still faces fierce competition from Apple's Mac OS, IBM's OS and UNIXbased OS, despite its dominance - roughly $90 \%$ of OS for desktop computers. Consequently, Microsoft is expanding its output, and its success does not have the problem associated with the monopoly. Unlike the firm in Figure 17, Microsoft's market behaviours do not exhibit any sign of either restricting output or raising price.

Secondly, unlike the firm with increasing marginal cost (depicted in Figure 17), computer software generally has a decreasing marginal or average cost because of its high fixed developing software cost and extremely low duplicating (variable) cost, resulting in the typical U-shaped average cost curve. For many digital products, their costs seem to be dominated by the increasing return in all output levels, a pattern observed in many natural monopolies. An efficient market result in such a case is to allow one firm to produce all necessary output in order to achieve the maximum economy of scale ${ }^{47}$. (Figure 18) Therefore, Microsoft's dominance in OS software is an efficient result due to the characteristics of the software industry. When a product has decreasing average cost or an increasing economy of scale, a competitive market often fails to achieve an efficient solution (no firms will produce the product). Therefore, Microsoft's dominance in the OS market may well be efficient.

Increasing returns, network effects, and the interoperability together seem to produce a monopolized but efficient market. All of these concepts indicate some sort of incentives that drive the market toward a single dominant product whereby consumers benefit from its dominance. With network externality, the value of a product goes up as more people have the same product. Microsoft's dominance is simply a manifestation of the network externality which relentlessly drives computer software to standardization. A network externality is an externality related to the number of users for a group of products.(Figure 19) However, an externality is no longer an externality if a market price already reflects the price of an external benefit or loss. For example, a computer operating system may have a positive externality in that its value increases as there are more people using the same product. This can be represented by an upward sloping benefit schedule for consumers ${ }^{48}$. Unlike other public goods, software manufacturers can and do raise their prices for that purpose. In this sense, the network externality is fully absorbed by the market price, and as a result there is no externality problem. ${ }^{49}$ We can certainly attribute Microsoft's dominance in OS to network effects.

Computer related technologies have today such big social significance that they cannot be left in the hands of businessmen. What shall happen is the transformation of capitalist monopolies into public utilities, operated under the democratic control of the working class. However, we know that competition

\footnotetext{
${ }^{46}$ Katz, M.L. and C. Shapiro, 1985. "Network externalities, competition, and compatibility." American Economic Review, 75(3): 424-440

${ }^{47}$ Arther, W.B., Increasing returns and the new world of business, Harvard Business Review, July-August, 1996, pp. $100-109$.

${ }^{48}$ Liebowitz, S.J. and S. E. Margolis, 1995. "Are network externalities a new source of market failure?" Research in Law and Economics, $17: 1-22$.

${ }^{49}$ Chou, C.-F. and O. Shy, 1990. Network effects without network externalities, International Journal of Industrial Organization, 8: 259270
} 
is not a quantity; it is a process by which entrepreneurs forecast and discover the preferences of consumers. Microsoft proved to be very good in such task, and punishing the company for its own success does not just weaken a free economy; it is clearly immoral.

\subsection{The model Windows - WMP $P^{50}$}

Consider a market with one producer of software (Microsoft), selling to heterogeneous software users who only differ with respect to how much they value the existence of the software WMP. There are $2 \eta$ potential WMP users who are divided in two groups: those who value WMP program and those who do not need it or use it, even if they have the all package of Windows software (with WMP included) because they prefer alternative softwares like RealNetworks, Apple’s Mac, etc.. ${ }^{51}$ Thus the potential consumers are composed of $\eta$ (type WMP) users who value WMP, and $\eta$ (type $\mathrm{O}^{52}$ ) who value other softwares and not WMP.

Each consumer buys at most one Windows. Thus, denoting by $q \geq 0$ the quantity sold by Microsoft, $q$ also stand for the actual number of WMP buyers. The utility function of each consumer type is given by (eq. 5.1) $)^{53}$

$$
\begin{aligned}
& U_{\text {WмP }} \equiv \begin{cases}\beta-p+\alpha q & \text { WMP installed } \\
\beta-p & \text { WMP not installed } \\
0 & \text { does not purchase the software }\end{cases} \\
& U_{O} \equiv \begin{cases}\beta-p & \text { purchase the Complete Windows Version } \\
0 & \text { does not purchase anything }\end{cases}
\end{aligned}
$$

where $\beta>0$ is the "basic" utility each consumer gets from buying a Windows package regardless of having WMP pre-installed. The parameter $\alpha$ (multiplying the total number of WMP buyers, $q$ ) measures the degree of importance WMP has to type WMP users. Hence, the product $\alpha q$ is the total utility gain from having a Complete Windows Version that benefits from all WMP features/options, the range of windows media format available and network effects. Finally, in my analysis I ignore sunk and fixed costs that are associated with the development and installation of the WMP software. Instead, I will focus on unit production cost of installing WMP in one package of Windows and not installing in others ${ }^{54}$. I therefore denote by $\mu_{W M P}$ the unit of a Windows version with the WMP included. I also denote by $\mu_{O}$ the unit cost of a Windows version with no WMP in. Then, I assume that $\mu_{W M P} \geq \mu_{O} \geq 0$, i.e. the

${ }^{50}$ Adapted from Shy, Oz, The Economics of Networks Industries, Cambridge University Press, USA 2001, p. 23 et sequentia.

${ }^{51}$ I assume only that there is a Windows package with WMP - the complete - and without it - the incomplete one.

52 "O" stands for "others".

53 "eq." stands for "equation".

${ }^{54}$ This cost is the one related with the creation of two separate versions of Windows available to consumers, as well as the (no-) installation time (resources) spent. 
production of a complete version of Windows is costly. Altogether, considering the assumption that Microsoft can only either choose to produce one type of Windows version, but not the both types, implies that if the monopoly produces $q$ units, its total production cost is given by (eq. 5.2)

$$
T C(q) \equiv \begin{cases}\mu_{W M P} & \text { if producing the complete version } \\ \mu_{O} & \text { if producing simple version (not with WMP) }\end{cases}
$$

I also assume that Microsoft makes decisions in a sequential manner divided into three stages.

- Stage I (Design): when Windows is designed, Microsoft decides whether to make the software with WMP or without by deciding whether to install/bundle it with the final version, at an additional cost of $\mu_{\text {WMP }}-\mu_{O}$ per package.

- Stage II (Pricing): the Windows design is taken as given and Microsoft chooses a uniform price which I denote $p$.

- Stage III (Consumers): each consumer/user decides whether to purchase one machine or not purchase at all. In making this decision, each consumer treats the total number of WMP users, $q$ as given ${ }^{55}$. After consumers' purchase decisions are done, Microsoft collects its revenue from them and profit is realized.

I look for a Subgame-Perfect Equilibrium ${ }^{56}$ and I solve this game backward by solving stage III, then stage II, and lastly stage I.

Stage III: Consumers' purchase decisions

Suppose first that the Windows software is produced with no WMP included. Then, eq. 5.2 implies that the total number of buyers is (eq. 5.3)

$$
q= \begin{cases}2 \eta & \text { If } p \leq \beta \\ 0 & \text { If } p>\beta\end{cases}
$$

Now, suppose that Microsoft bundles WMP in each Windows version, thereby making all versions complete. Then, eq. 5.2 implies that total number of buyers is (eq. 5.4)

$$
q= \begin{cases}2 \eta & \text { If } p \leq \beta \\ \eta & \text { If } \beta<p \leq \beta+\alpha \eta \\ 0 & \text { If } p>\beta+\alpha \eta\end{cases}
$$

\footnotetext{
55 Consumers have a perfect foresight and at the time of purchase they can correctly anticipate how many consumers will buy a complete Windows version. I rule out coordination failures and $U(q>0)>U(q=0)$

${ }^{56}$ An outcome is said to be a subgame perfect equilibrium (SPE) if it induces a Nash equilibrium in every subgame of the original game. Definition from Shy, OZ, The Economics of Network Industries, Cambridge University Press, USA 2001, p.303.
} 


\section{Stage II: Microsoft selects a price}

In this stage, Microsoft selects a profit-maximizing price subject to consumers' demand functions eq. 5.3 and eq. 5.4. If the version is complete, eq. 5.3 applies and Microsoft's profit maximizing price is If $p=\beta$, yielding a profit of (eq. 5.5) $\pi_{W M P}=\left(\beta-\mu_{\text {WMP }}\right) 2 \eta$

If the version is simple (no WMP installed), eq. 5.4 applies and the profit of Microsoft as a function of price is (eq. 5.6)

$$
\pi_{O}= \begin{cases}\left(\beta+\alpha \eta-\mu_{O}\right) \eta & \text { If } p=\beta+\alpha \eta \\ \left(\beta-\mu_{O}\right) 2 \eta & \text { If } p=\beta\end{cases}
$$

\section{Stage I: Microsoft WMP inclusion decision}

In the first stage, Microsoft decides how to design its Windows version, knowing that bundling WMP would raise the production cost by $\Delta \mu \equiv \mu_{\text {WMP }}-\mu_{O}$.

Comparing eq. 5.5 with the second part of eq. 5.6 reveals that the monopoly will never design the full complete version and charge only $p=\beta$, as there is no point in investing in WMP if consumers are not required to pay for it (note that this is not the actual real life situation). Hence, in making its decision, Microsoft need to compare eq. 5.5 with the first part of eq. 5.6. Therefore, Microsoft will produce complete versions if (eq. 5.7)

$$
\left(\beta+\alpha \eta-\mu_{\text {WMP }}\right) \eta \geq\left(\beta-\mu_{O}\right) 2 \eta
$$

Equation 5.7 reveals that an increase in the network externality parameter $\alpha$ will increase the parameter range where Microsoft will choose to design a full complete version of Windows. Finally, eq. 5.7 can be simplified to (eq. 5.8) $\quad \mu_{W M P} \leq \alpha \eta-\beta+2 \mu_{O}$

which has the interpretation that a complete version is profitable if the cost of making one version with WMP does not exceed the gain in revenue by increasing the price for consumers seeking WMP packages, $\alpha \eta$, minus the loss from giving up on the other consumers, $\beta$ plus the "saving" made by not producing twice as many simple Windows versions.

Now I should ask if there is any market failure. A natural question to ask at this point is whether a Microsoft monopoly reduces social welfare by over- or under-provision of full complete Windows versions. I define society's social welfare as the summing up of consumers' utilities and Microsoft's profit. Suppose that the "Social Planner" decides on making single versions. Then the social welfare is given by (eq. 5.9)

$$
W_{O}=\eta U_{W M P}+\eta U_{O}+\pi=\eta(\beta-p)+\eta(\beta-p)+2 \eta\left(p-\mu_{O}\right)=2 \eta\left(\beta-\mu_{O}\right)
$$

Now suppose that the "Social Planner" decides on making full complete Windows versions, and selling them to all consumers! Then, the social welfare is given by (eq. 5.10) 


$$
W_{W M P}=\eta U_{W M P}+\eta U_{O}+\pi=\eta[\beta+\alpha(\eta+\eta)-p]+\eta(\beta-p)+2 \eta\left(p-\mu_{W M P}\right)=2 \eta\left(\beta+\alpha \eta-\mu_{W M P}\right)
$$

Comparing eq. 5.9 with eq. 5.10 yields that full complete versions is socially preferred if (eq. 5.11)

$$
\mu_{W M P} \leq \alpha \eta+\mu_{O}
$$

The conditions given in eq. 5.8. and 5.11 are drawn in Figure 20, which divides the $\mu_{\mathrm{WMP}}-\mu_{\mathrm{O}}$ space in three regions: in region I, the unit cost of producing full complete versions is very high comparing to single Windows versions, hence both the social planner and Microsoft will choose single versions. Region III reflects the exact opposite extreme, and, in contrast, region II illustrates a parameter range where a market failure occurs since the monopoly will produce single versions, but full complete versions is socially optimal. The reason for that is because Microsoft is unable to price discriminate between the two groups of consumers.

Summing up, the first region is not what we observe in reality; the third one is the actual situation; and finally the second one illustrates the possible long-run market failure case if the "Regulatory Agency" oblige Microsoft to sell to different Windows packages and consumers don't desire that to happen. So everything is in the hands of demand and consumer's preferences and regulatory agencies should simply follow those trends and not regulate simple because it should be done. There are a lot of pros and cons to evaluate in terms of societal welfare. Note that the model presented could have been formulated so that other conclusion could have emerged as the efficient one. In order to have different conclusions and possible solutions to the so called "Microsoft Monopoly" just play with the parameters and see the consequences in terms of the model.

\subsubsection{Software pricing and Market Segmentation ${ }^{57}$}

Price discrimination according to quality is common in the software industry. The most widely used quality differentiation involves removal of key features from the program and selling the reduced (simple) version to consumers with low-willingness to pay.

Let $\theta \quad(\theta>1)$ denote the exogenously-given number of extra features (in this case just the WMP) embedded in Windows. There are two types of consumers, those who are Media Friendly (hereafter just M) and use WMP to play audio, video, etc files, and those who are Light Users (hereafter L) of Windows and just use its basic office tools, without the fancy extra features. I assume that there are $\eta \mathrm{M}$ type with a utility function given by (eq. 5.12)

$$
U^{M} \equiv \begin{cases}(1+\theta) q-p & \text { If buys Windows with WMP } \\ q-p & \text { If buys Windows with no WMP } \\ 0 & \text { If does not buy Windows }\end{cases}
$$

\footnotetext{
${ }^{57}$ Based on Shy, Oz, The Economics of Networks Industries, Cambridge University Press, USA 2001, p. 70 et sequentia.
} 
In addition there are $\eta \mathrm{L}$ type users whose utility function is given by (eq. 5.13)

$$
U^{L} \equiv \begin{cases}q-p & \text { If buys Windows with or without WMP } \\ 0 & \text { If does not buy Windows }\end{cases}
$$

Assume that the full version (actual Windows package sold in stores) has already been developed so all development costs are considered as sunk. Assume that the software duplication and distribution of each copy is zero (i.e. zero marginal cost). However, let $\phi_{r}$ be the cost of developing a reduced version of Windows without WMP embedded.

Suppose that only the complete version is offered for sale at a price denoted by $p$. facing the types of consumers, the profit maximizing prices to consider are either a low prices, $p_{l}=2 \eta$, in which both types of consumers purchase the Windows complete version; or setting a high price, $p_{h}=(1+\theta) \eta$, in which only M type users buy. Hence, eq. 5.12 and 5.13 imply that the number of Windows buyers and corresponding profit levels as functions of these prices are (eq. 5.15)

$$
q=\left\{\begin{array}{ll}
\eta & \text { If } p=(1+\theta) \eta \\
2 \eta & \text { If } p=2 \eta
\end{array} \quad \text { and } \pi= \begin{cases}\eta^{2}(1+\theta) & \text { If } p=(1+\theta) \eta \\
4 \eta^{2} & \text { if } p=2 \eta\end{cases}\right.
$$

When only the complete version is sold, Microsoft will charge a high price, $p=p_{h}=(1+\theta) \eta$ if $\theta>3$, in which case only M type users buy this version; and a low price $p=p_{h}=2 \eta$, if $\theta \leq 3$, in which case the entire market is served.

Now suppose that Microsoft sinks $\phi_{r}$ into creating a reduced version of Windows that does not include WMP. Let $p_{r}$ denote the price of the reduced version and $p$ the price of the complete version. Clearly if $p>p_{r}$, L type users will not purchase the complete version since WMP do not enhance their utility. Hence, if Microsoft wants to sell both versions, prices must be set so that (eq. 5.16)

$$
\phi(1+\theta) 2 \eta-p \geq 2 \eta-p_{r} ; \rightarrow \text { or } \rightarrow p-p_{r} \leq 2 \eta \theta
$$

meaning that prices should be set so that the utility of a $\mathrm{M}$ type user when buying the complete version exceeds the utility from buying the reduced version despite the fact the price of the reduced version is lower.

The method of finding the profit maximizing prices satisfying the condition given in eq. 5.16 is to set the lower price equal to the $\mathrm{L}$ type users' reservation price, and then add $2 \eta \theta$ which is the extra amount M type users are willing to pay for the extra features. Thus, $p_{r}=2 \eta$ and $p=2 \eta(1+\theta)$, yielding a profit level of (eq. 5.17)

$$
\pi=\eta p+\eta p_{r}-\phi_{r}=2 \eta^{2}(1+\phi)+2 \eta^{2}-\phi_{r}
$$

If $\phi_{r}<2 \eta^{2} \theta$ Microsoft makes a higher profit by selling two versions of software and by selling the version that is more costly to develop at a lower price. 
Ultima ratio, once again different results could have been obtained simply by playing with the parameters of the model above, but the main conclusion is that "it depends" whether it is more profitable for Microsoft to sell two versions as the Commission imposed or just sell one. In any case, Microsoft's profit is just one side of the overall welfare, implying that one also should look to consumer's surplus in the above analysis. I did not do that because this was just to show a sample of what economic models can do in explaining real life situations. From here everything is possible...

As a final remark, in this Microsoft saga, regulatory agencies may some day conclude that the costs of constant regulatory battles-legal costs, fines, bad publicity, and bad relationships with governments - exceed the benefits of its Windows monopoly.

\section{Conclusion}

A global world with a single marketplace brings also global innovation and greater sources of ideas and inventions ${ }^{58}$. Being first had long implied advantages over later entrants (e.g. Microsoft) but is not longer a guarantee for necessary research must be maintained to stay ahead of competitors.

Monopoly tends to have different effects to owners vis-à-vis consumers. Common wisdom among economists further suggests that the negative impact on consumers tends to dominate relative to the positive profit effects associated with monopoly. This divergence explains, in a word, why governments employ antitrust policies. However, technological progress, network externalities and international competition all represent disturbances relative to the common wisdom outlined above. With the innovation intense competition typical for the information economy, innovation is increasingly driven by companies that gain temporary monopoly power, but enjoy it only for a short time before being replaced by a firm with a better product. Hence, information economy may feature more monopolies than the traditional sectors of the economy, but that these monopolies may harm consumers only for a limited period of time. Indeed, if these market dynamics encourage innovation, consumers might actually benefit from the dynamic efficiency generated by high market concentration. Analogously, the presence of network externalities offers additional strategic instruments whereby incumbent firms might be able to abuse dominant market positions.

With this paper I have tried to picture an overview of the actual and valid EU Competition Regulation and also a flavor of the future developments that will take place concerning the Internationalization of Antitrust Policy. This, indeed, is an issue of current big debate and countries and organizations are actually coordinating efforts by performing bilateral and multilateral agreements ${ }^{59}$, so that in the future we have an uniformly applicable antitrust system. Furthermore, I have demonstrated, by analyzing two past but recent EU cases (Volvo-Scania and Microsoft-WMP) that consumers are the sine qua non point of antitrust regulation and that depending which type of industry we are looking at, the consequences and solutions can vary, namely in the "New Economy” of information and digital goods.

\footnotetext{
${ }^{58}$ See Bergel, Inga, Effects of globalization on antitrust policy, November $4^{\text {th }}, 1997$.

59 See International antitrust co-operation: Bilateralism or Multilateralism?, Comments of K. von Finckenstein QC, Commissioner of Competition, to the ABA section of Antitrust Laws / CBA National Competition Law Section Conference International antitrust Issues: Pacific Rim and Beyond (Vancouver, 31 May 2001).
} 
The economic model presented was a way to show how all these things can interact together as well as a sample of what can be done.

The most important areas in EU Competition Policy (Mergers and Abuse of Dominant Position) have a lot of points in common and a decentralized application system of the EC antitrust rules could led to uncertainties in the interpretation of law and this will bear the danger that decision-making bodies might decide similar cases in dissimilar ways $^{60}$ - therefore the need for international cooperation. Rony Gerrits, an associate at Morrison \& Foerster LLP in Brussels, said once: “Antitrust is about economics, not about the question of whether or not your agreement contains a certain clause." The picture that emerges [...] [concerning competition policy] in the enlarged EU is one of astonishing diversity and total underdevelopment."

Ultima ratio, antitrust law is, per definitionem, the study of competition and it is centred on certain principles; the primary one is that society is better off if markets behave competitively. However that is no longer true if we look to computer related industries; the former antitrust regulation as we know it, will have to change and continuously follow and adapt to this "New Economy” - from onwards one should have ex-ante and ex-post "New Economy” Competition Policy.

${ }^{60}$ See Goldsmith, P.I.B., Lanz C., Maybe Definitely - Definitely Maybe? EC Competition Law - Is the time ripe for Freform?, Eipascope, 2/2001, p. 17 


\section{Appendix}

Figure 1: Figures below present number of new antitrust cases opened in years 1993-2002.
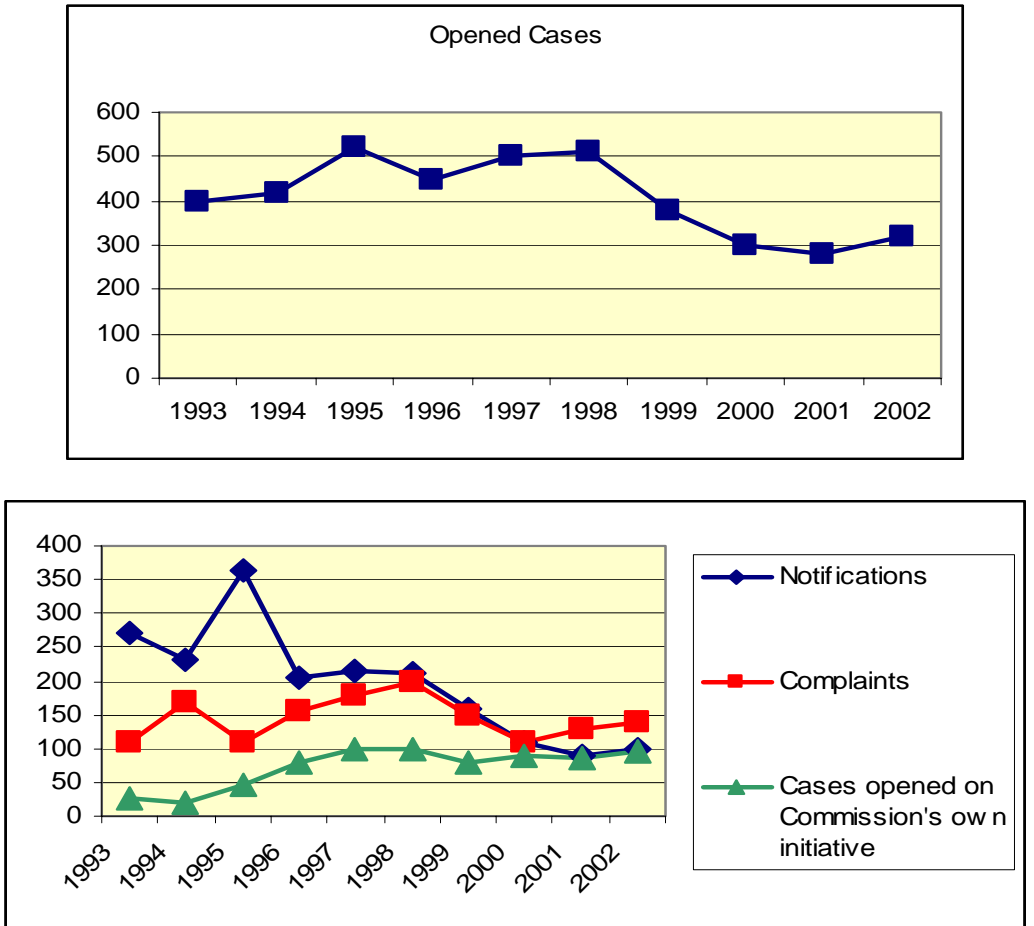

Source: Statistical data come from XXVIII and XXXII Reports on Competition Policy

Figure 2: Number of decisions on Mergers \& Acquisitions taken by the Commission
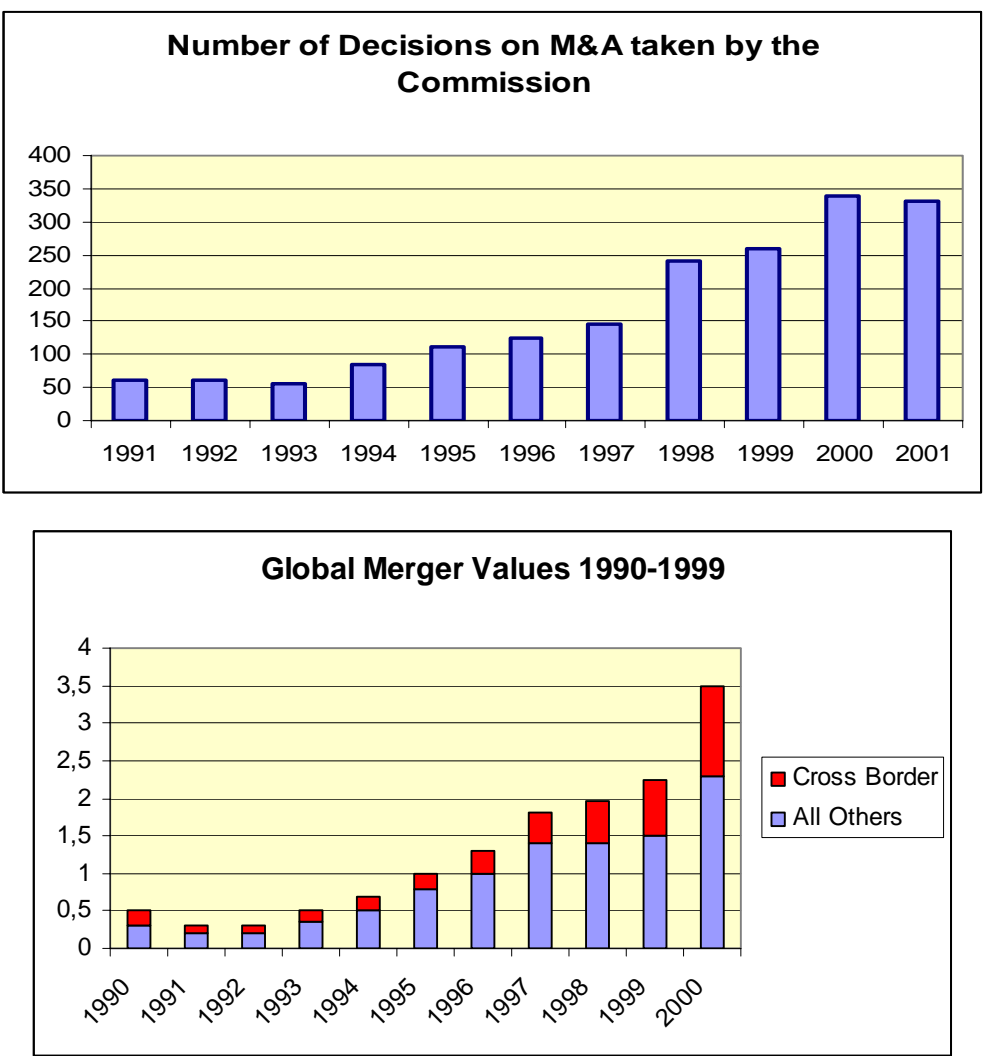

Source: Economist, 1999, Renner, 2000; UNCTAD, 2001 
Figure 3: Powers under the EU Merger Control Regulation

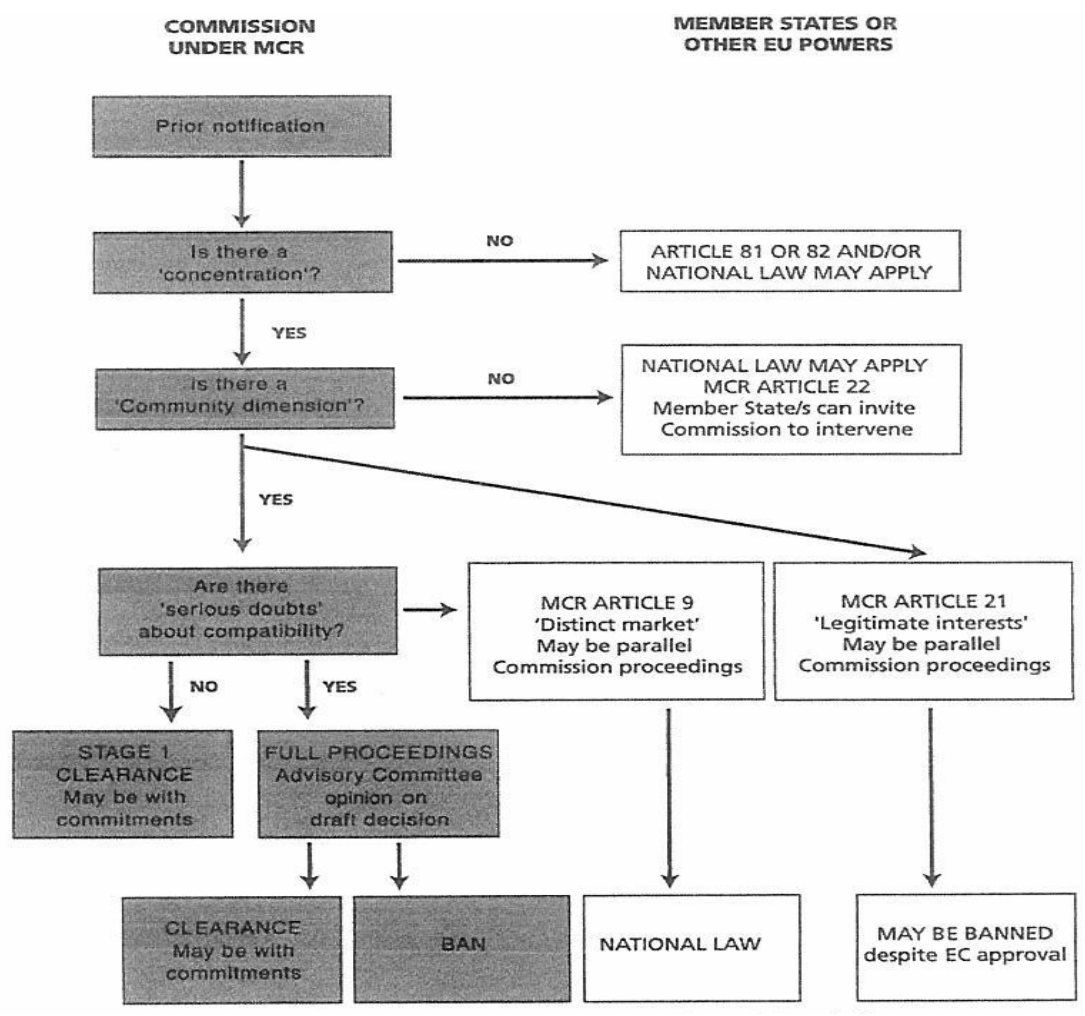

Source: http://www.econ.kuleuven.be/tew/academic/strateg/Students/Syllabi/D145\%20M\&A\%202.PPT

Figure 4: Product line and geographical spread of the European commercial vehicles manufactures

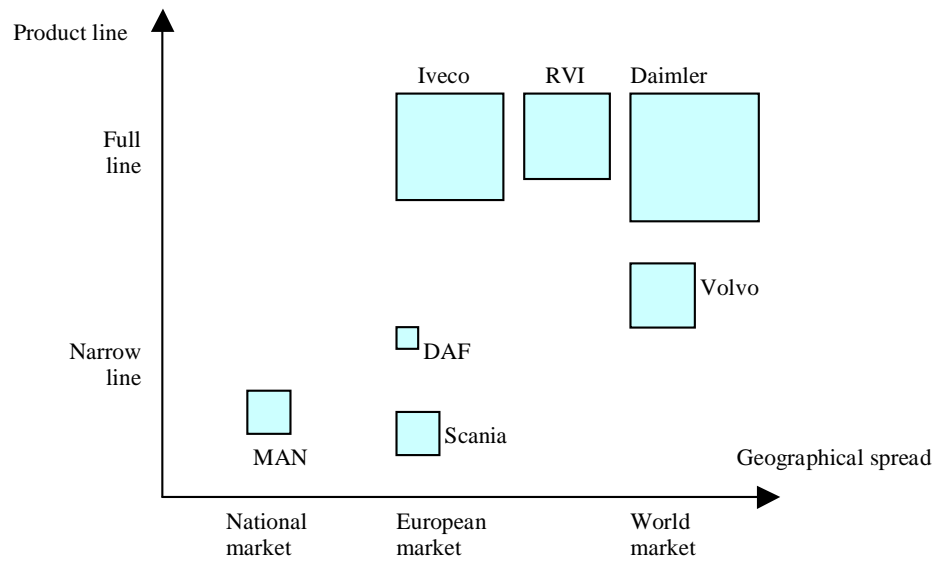

Figure 5: Increased concentration in European heavy trucks industry
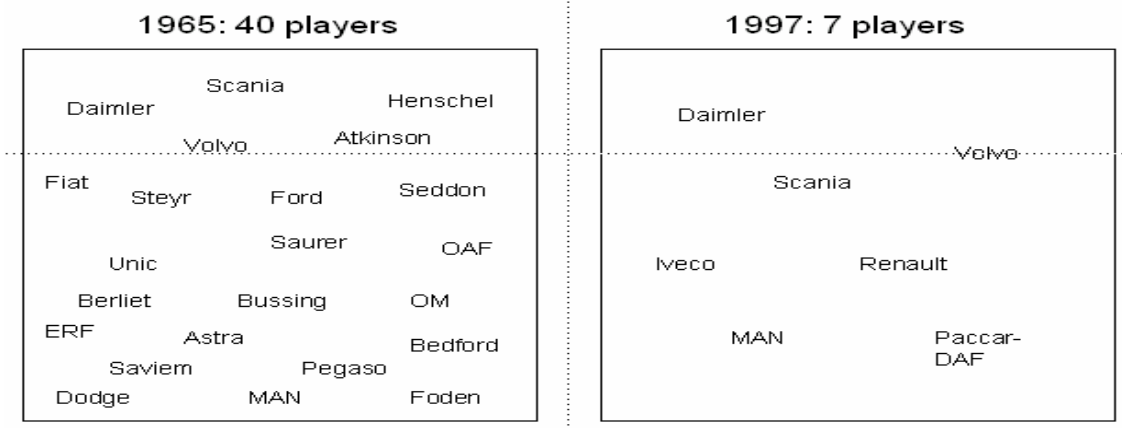

Source: http://www.econ.kuleuven.be/tew/academic/strateg/Students/Syllabi/D145\%20M\&A\%202.PPT 
Figure 6: Rigid Trucks and tractor trucks

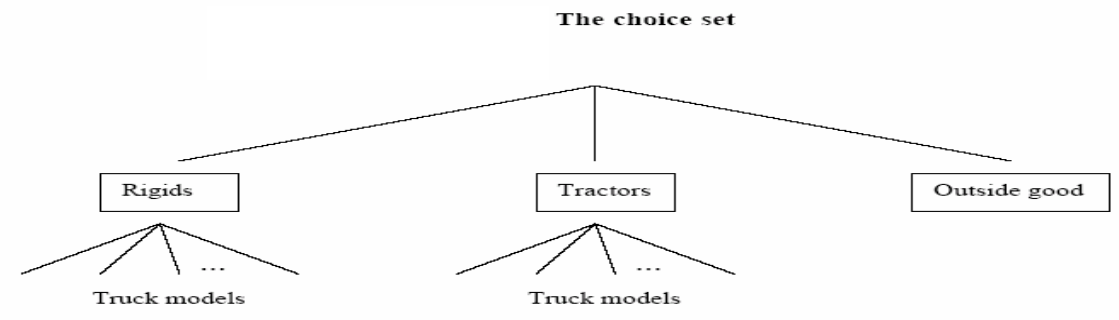

Source: idei.fr/doc/by/ivaldi/iv_merger_v04.pdf

Figure 7: Market shares per country in 1998

\begin{tabular}{|l|c|c|c|c|c|c|c|}
\hline \multicolumn{7}{|c|}{ Market Shares per country in 1998 } \\
\hline & Daf & Daimler & Iveco & Man & Renault & Scania & Volvo \\
\hline AU & 5 & 18 & 6 & $3-4$ & 4 & 16 & 12 \\
BE & 17 & 18 & 6 & 11 & 8 & 17 & 23 \\
FI & 4 & 18 & 7 & 10 & 3 & 30 & 29 \\
DK & 0 & 10 & 4 & 3 & 18 & 31 & 34 \\
FR & 8 & 16 & 8 & 5 & 38 & 9 & 14 \\
GE & 5 & 42 & 6 & 26 & 2 & 9 & 8 \\
GR & 3 & 36 & 2 & 12 & 3 & 17 & 24 \\
IR & 13 & 9 & 8 & 6 & 3 & 27 & 22 \\
IT & 4 & 16 & 41 & 6 & 9 & 12 & 12 \\
LU & 15 & 28 & 8 & 14 & 10 & 15 & 11 \\
NE & 33 & 12 & 3 & 9 & 3 & 23 & 16 \\
NO & 4 & 9 & 2 & 12 & 1 & 32 & 38 \\
PO & 14 & 12 & 7 & 6 & 17 & 19 & 25 \\
SP & 9 & 19 & 20 & 8 & 19 & 16 & 13 \\
SW & 2 & 6 & 0 & 0 & 1 & 46 & 45 \\
UK & 18 & 9 & 9 & 7 & 6 & 19 & 18 \\
\hline EEA & 11 & 21 & 11 & 13 & 12 & 16 & 15 \\
\hline
\end{tabular}

Market shares Trucks 10-15.9T GVW Western Europe (1999)

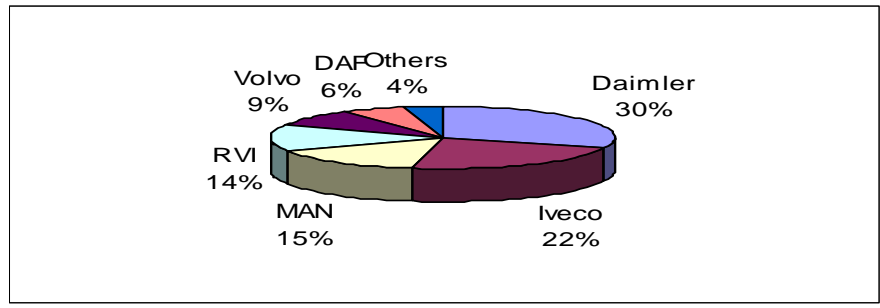

Market shares trucks >16T GVW Western Europe (1999)

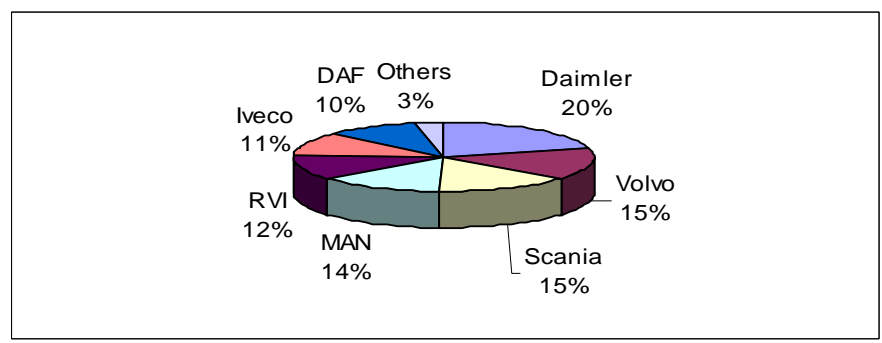

Source: http://www.econ.kuleuven.be/tew/academic/strateg/Students/Syllabi/D145\%20M\&A\%202.PPT 
Figure 8: Market Share Variation in 1998:

\begin{tabular}{|c|c|c|c|c|c|c|c|}
\hline & Volvo & Scania & Daimler & MAN & RVI & Iveco & DAF \\
\hline EEA average & 15,2 & 15,6 & 20,5 & 12,6 & 11,9 & 10,6 & 10,5 \\
\hline Sweden & 45 & 46 & 6 & 0 & 1 & 0 & 2 \\
\hline Finland & 34 & 31 & 10 & 3 & 18 & 4 & 0 \\
\hline Denmark & 29 & 30 & 18 & 10 & 3 & 7 & 4 \\
\hline UK & 18 & 19 & 9 & 7 & 6 & 9 & 18 \\
\hline Ireland & 22 & 27 & 9 & 6 & 3 & 8 & 13 \\
\hline Germany & 8 & 9 & 42 & 26 & 2 & 6 & 5 \\
\hline Austria & 12 & 16 & 18 & 34 & 4 & 6 & 9 \\
\hline France & 14 & 9 & 16 & 5 & 38 & 8 & 8 \\
\hline Belgium & 23 & 17 & 18 & 11 & 8 & 6 & 17 \\
\hline Luxembourg & 11 & 15 & 28 & 14 & 10 & 8 & 15 \\
\hline Netherlands & 16 & 23 & 12 & 9 & 3 & 3 & 33 \\
\hline Italy & 12 & 12 & 16 & 6 & 9 & 41 & 4 \\
\hline Spain & 13 & 16 & 19 & 8 & 19 & 20 & 9 \\
\hline Portugal & 25 & 19 & 12 & 6 & 17 & 7 & 14 \\
\hline Greece & 24 & 17 & 36 & 12 & 3 & 2 & 3 \\
\hline Norway & 38 & 32 & 9 & 12 & 1 & 2 & 4 \\
\hline
\end{tabular}

Source: http://www.econ.kuleuven.be/tew/academic/strateg/Students/Syllabi/D145\%20M\&A\%202.PPT

Figure 9: Price Elasticity of total market demand

\begin{tabular}{|l|c|c|}
\hline \multirow{2}{*}{ Austria } & \multicolumn{2}{|c|}{ Potential market factor } \\
\cline { 2 - 3 } Belgium & $\mathbf{r}=\mathbf{0 , 5}$ & $\mathbf{r}=\mathbf{3 , 0}$ \\
Denmark & $-0,49$ & $-1,53$ \\
Finland & $-0,49$ & $-1,11$ \\
France & $-0,47$ & $-1,02$ \\
Germany & $-0,38$ & $-0,098$ \\
Greece & $-0,44$ & $-1,17$ \\
Ireland & $-0,53$ & $-1,52$ \\
Italy & $-0,28$ & $-0,63$ \\
Luxembourg & $-0,34$ & $-10,5$ \\
Netherlands & $-0,61$ & $-1,63$ \\
Norway & $-0,41$ & $-0,94$ \\
Portugal & $-0,59$ & $-1,54$ \\
Spain & $-0,56$ & $-1,14$ \\
Sweden & $-0,46$ & $-1,21$ \\
UK & $-0,44$ & $-1,22$ \\
\hline
\end{tabular}

Note: the price elasticity of total market demand in this differentiated product model is defined as the percentage change in total demand for trucks when the prices of all trucks increase by one percent. 


\section{Figure 10: Efficiency defence}

\#Economies of scale

Table 1 - Minimum annual volumes for optimal production

\begin{tabular}{lr}
\hline Cabins & $200000+$ \\
Frame & $40000+$ \\
Axles & $40000+$ \\
Engines & $200000^{+}$ \\
Final assembly & $100000+$
\end{tabular}

Source: Estimates from Muller and Owen, 1981

\#R\&D

Table 1 - Financial requirements for the construction of a commercial vehicle - 1982,

$£ m$

Design and development costs:

complete new truck

truck with existing components

new cabin

new axles

new engine

new gearbox

$120-200$

50

60

80

$150-200$

$50-200$

Assembly unit cost

$150-300$

Sub-assembly unit costs

150

Research and design department

40

Company investment for a new series of

350

commercial vehicles(using existing components)

Source: Estimates from Muller and Owen, 1981

Figure 11: Percent price changes after merger

\begin{tabular}{|l|c|c|c|c|}
\hline & \multicolumn{2}{c}{ Volvo/Scania } & \multicolumn{2}{c|}{ Competitors } \\
& Rigid & Tractor & Rigid & Tractor \\
\hline Austria & 1,69 & 2,15 & 0,05 & 0,08 \\
Belgium & 6,75 & 5,41 & 0,14 & 0,16 \\
Denmark & 11,55 & 8,17 & 0,26 & 0,19 \\
Finland & 10,03 & 7,83 & 0,39 & 0,24 \\
France & 2,97 & 2,97 & 0,09 & 0,08 \\
Germany & 1,65 & 2,19 & 0,04 & 0,06 \\
Greece & 4,98 & 5,39 & 0,25 & 0,26 \\
Ireland & 10,87 & 7,36 & 0,21 & 0,3 \\
Italy & 2,02 & 1,49 & 0,07 & 0,07 \\
Luxembourg & 3,33 & 1,65 & 0,05 & 0,05 \\
Netherlands & 3,56 & 3,47 & 0,21 & 0,16 \\
Norway & 13,17 & 8,63 & 0,32 & 0,28 \\
Portugal & 6,67 & 5,06 & 0,19 & 0,12 \\
Spain & 3,65 & 2,98 & 0,06 & 0,08 \\
Sweden & 22,34 & 12,64 & 0,47 & 0,32 \\
UK & 7,15 & 4,79 & 0,27 & 0,12 \\
\hline
\end{tabular}


Figure 12: Thresholds - overview

\begin{tabular}{|c|c|c|c|c|}
\hline & \multirow{2}{*}{$\begin{array}{l}\text { A firm with a } \\
\text { paramount } \\
\text { position }\end{array}$} & \multicolumn{2}{|c|}{ Non-collusive oligopolies } & \multirow[t]{2}{*}{ Co-ordination } \\
\hline & & $\begin{array}{l}\text { Homogeneous } \\
\text { prodiucts }\end{array}$ & $\begin{array}{l}\text { Differentiated } \\
\text { products }\end{array}$ & \\
\hline $\begin{array}{l}\text { - Uritikely to be } \cdots \\
\text { investigated }\end{array}$ & \multicolumn{4}{|c|}{$\mathrm{HH} \mathrm{H}<[1000]$} \\
\hline $\begin{array}{l}\text { Indication that } \\
\text { merger may not } \\
\text { impede signific antly } \\
\text { effective } \\
\text { competition }\end{array}$ & & & $M S<[25 \%]$ & \\
\hline $\begin{array}{l}\text { Is likely to raise } \\
\text { serious doubts }\end{array}$ & & $\begin{array}{c}\mathrm{HHI}>2000] \\
\text { and } \\
\Delta \mathrm{HH}>[150]\end{array}$ & & \\
\hline $\begin{array}{l}\text { Indication of } \\
\text { dominance }\end{array}$ & $M S>[50 \%]$ & & & \\
\hline
\end{tabular}

Source: http://www.econ.kuleuven.be/tew/academic/strateg/Students/Syllabi/D145\%20M\&A\%202.PPT

Figure 13: Welfare analysis of the merger

\begin{tabular}{|c|c|c|c|c|c|c|}
\hline & $\begin{array}{c}\text { Premerger } \\
\text { consumer } \\
\text { surplus } \\
\end{array}$ & $\begin{array}{c}\text { Change } \\
\text { in consumer } \\
\text { surplus (\%) }\end{array}$ & $\begin{array}{c}\text { Premerger } \\
\text { industry } \\
\text { profit (\%) }\end{array}$ & $\begin{array}{l}\text { Change in } \\
\text { industry } \\
\text { profit (\%) }\end{array}$ & $\begin{array}{c}\text { Premerger } \\
\text { total } \\
\text { welfare } \\
\end{array}$ & $\begin{array}{c}\text { Change in } \\
\text { total } \\
\text { welfare (\%) }\end{array}$ \\
\hline Austria & 100 & $-1,09$ & 65,8 & 0,77 & 165,8 & $-0,35$ \\
\hline Belgium & 97,8 & $-3,05$ & 63,9 & 1,73 & 161,6 & $-1,16$ \\
\hline Denmark & 97,4 & $-6,02$ & 65,6 & 2,78 & 163 & $-2,48$ \\
\hline Finland & 98,6 & $-8,44$ & 67,9 & 3,65 & 166,6 & $-3,51$ \\
\hline France & 98,9 & $-1,04$ & 65,7 & 0,71 & 164,6 & $-0,34$ \\
\hline Germany & 99,5 & $-0,62$ & 67,9 & 0,45 & 167,4 & $-0,19$ \\
\hline Greece & 97,7 & $-3,46$ & 68,3 & 1,8 & 166 & $-1,3$ \\
\hline Ireland & 99,9 & -7 & 66,6 & 3,33 & 166,5 & $-2,87$ \\
\hline Italy & 99 & $-1,03$ & 66,9 & 0,71 & 165,9 & $-0,33$ \\
\hline Luxembourg & 97,8 & $-0,59$ & 68,4 & 0,38 & 166,2 & $-0,19$ \\
\hline Netherlands & 98,8 & $-2,85$ & 67,1 & 0,168 & 165,9 & $-1,02$ \\
\hline Norway & 96,9 & $-10,71$ & 69 & 3,78 & 165,8 & $-4,68$ \\
\hline Portugal & 98,9 & $-3,34$ & 64,1 & 1,92 & 163 & $-1,27$ \\
\hline Spain & 99,2 & $-1,39$ & 63,7 & 0,94 & 162,9 & $-0,48$ \\
\hline Sweden & 97,4 & $-17,77$ & 73,2 & 4,89 & 170,5 & $-8,05$ \\
\hline UK & 97,8 & $-3,77$ & 64,5 & 2,05 & 162,3 & $-1,46$ \\
\hline
\end{tabular}

Source: idei.fr/doc/by/ivaldi/iv_merger_v04.pdf

Figure 14: Welfare analysis in the presence of cost efficiencies

\begin{tabular}{|l|c|c|c|c|c|c|}
\hline \multirow{2}{*}{} & \multicolumn{3}{|c|}{ Change in consumer surplus } & \multicolumn{3}{c|}{ Change in total welfare } \\
\cline { 2 - 7 } & \multicolumn{3}{|c|}{ cost effeciency of } & \multicolumn{3}{c|}{ cost effeciency of } \\
\cline { 2 - 7 } & $\mathbf{0} \%$ & $\mathbf{5 \%}$ & $\mathbf{1 0 \%}$ & $\mathbf{0 \%}$ & $\mathbf{5 \%}$ & $\mathbf{1 0 \%}$ \\
\hline Austria & $-10,9$ & 0,02 & 1,19 & $-0,35$ & 0,01 & 0,44 \\
Belgium & $-3,05$ & $-1,41$ & 0,31 & $-1,16$ & $-0,56$ & 0,14 \\
Denmark & $-6,02$ & $-4,25$ & $-2,42$ & $-2,48$ & $-1,79$ & $-1,03$ \\
Finland & $-8,44$ & $-6,93$ & $-5,37$ & $-3,51$ & $-2,93$ & $-2,29$ \\
France & $-1,04$ & 0,1 & 1,29 & $-0,34$ & 0,04 & 0,48 \\
Germany & $-0,62$ & 0,24 & 1,15 & $-0,19$ & 0,08 & 0,39 \\
Greece & $-3,46$ & $-2,06$ & $-0,6$ & $-1,3$ & $-0,8$ & $-0,24$
\end{tabular}




\begin{tabular}{l|c|c|c|c|c|c|} 
Ireland & -7 & $-5,15$ & $-3,24$ & $-2,87$ & $-2,16$ & $-1,38$ \\
Italy & $-1,03$ & $-0,02$ & 1,04 & $-0,33$ & 0 & 0,38 \\
Luxembourg & $-0,59$ & 0,24 & 1,11 & $-0,19$ & 0,08 & 0,39 \\
Netherlands & $-2,85$ & $-1,3$ & 0,32 & $-1,02$ & $-0,48$ & 0,14 \\
Norway & $-10,71$ & $-8,95$ & $-7,14$ & $-4,68$ & $-3,96$ & $-3,19$ \\
Portugal & $-3,34$ & $-1,78$ & $-0,15$ & $-1,27$ & $-0,7$ & $-0,05$ \\
Spain & $-1,39$ & $-0,2$ & 1,06 & $-0,48$ & $-0,07$ & 0,41 \\
Sweden & $-17,77$ & $-15,89$ & $-13,95$ & $-8,05$ & $-7,23$ & $-6,38$ \\
UK & $-3,77$ & $-2,13$ & $-0,41$ & $-1,46$ & $-0,85$ & $-0,15$ \\
\hline
\end{tabular}

Source: idei.fr/doc/by/ivaldi/iv_merger_v04.pdf

Figure 15: Microsoft Market Share

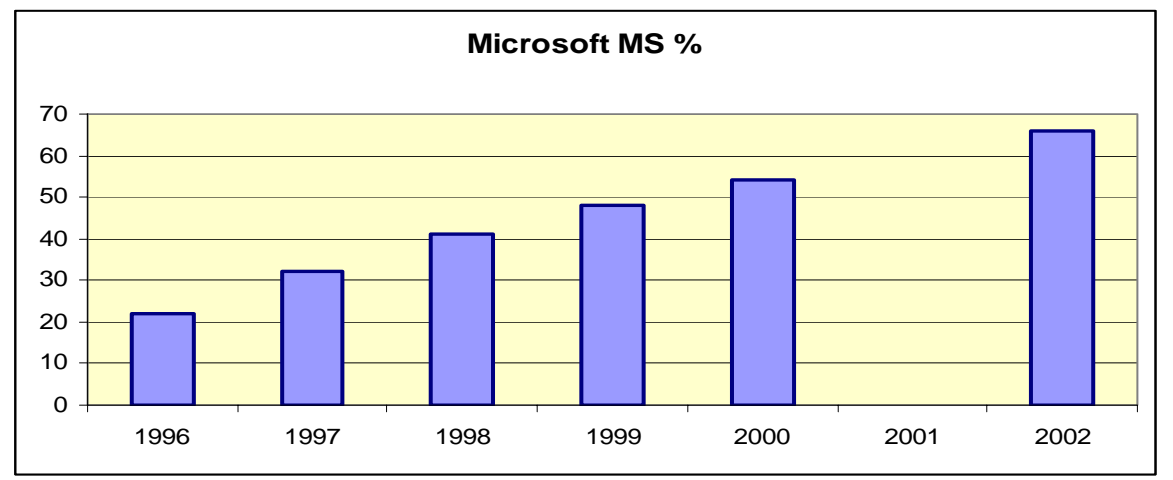

Source: http://www.cerna.ensmp.fr/Enseignement/CoursEcoIndus/SupportsdeCours/ECvsMC.pdf

Figure 16: Average number of monthly users

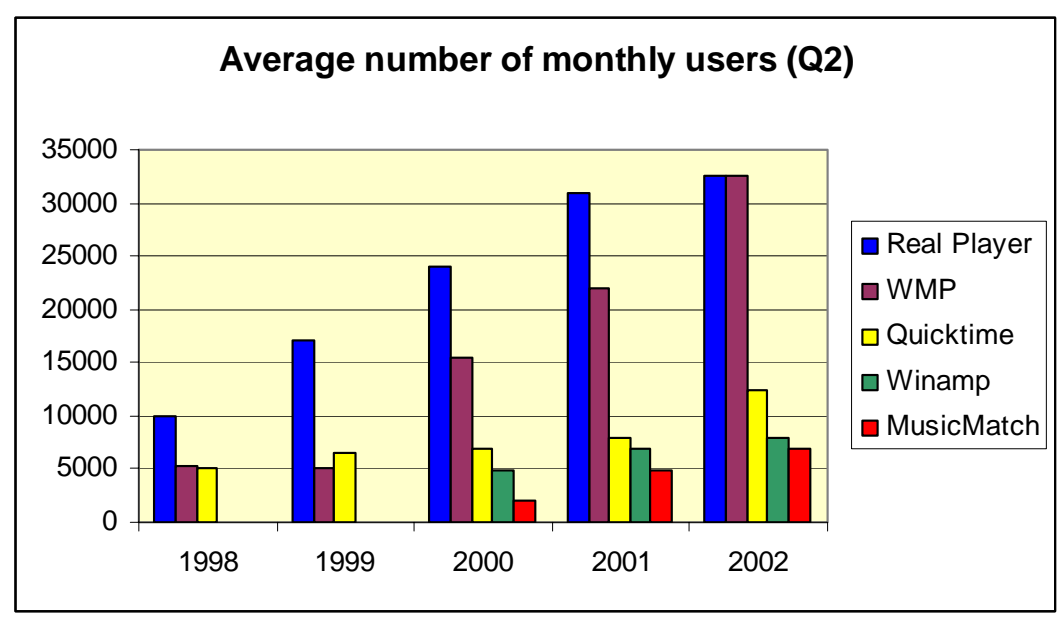

Source: http://www.cerna.ensmp.fr/Enseignement/CoursEcoIndus/SupportsdeCours/ECvsMC.pdf

Figure 17: The Monopoly Problem

The monopoly problem is straightforward. The firm in the graph below is assumed to have monopoly market power and can restrict output and raise price only because it does not face competition. To maximize its profit, the firm operates at the output level when its marginal cost is equal to marginal revenue $(\mathrm{Qm})$. At that output level, market price is determined by the demand $(\mathrm{Pm})$, which is greater than marginal cost (MC). The firm's profit is (Pm - MC) Qm > 0. At Qm level of production, consumers' 
willingness to pay, Pm, is greater than the cost of producing the product (MC). Thus society will be better off if more resources are allocated into this industry leading to a greater output level at Qc and lower price Pc.

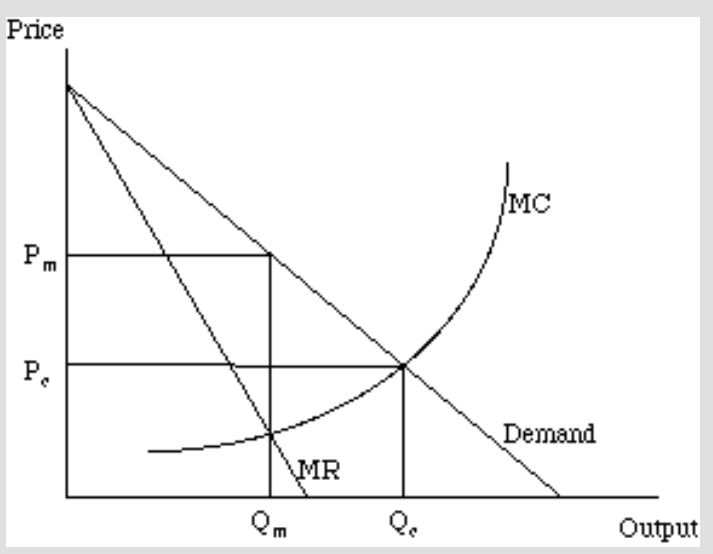

Figure 18: Economies of Scale

\section{Economies of scale}
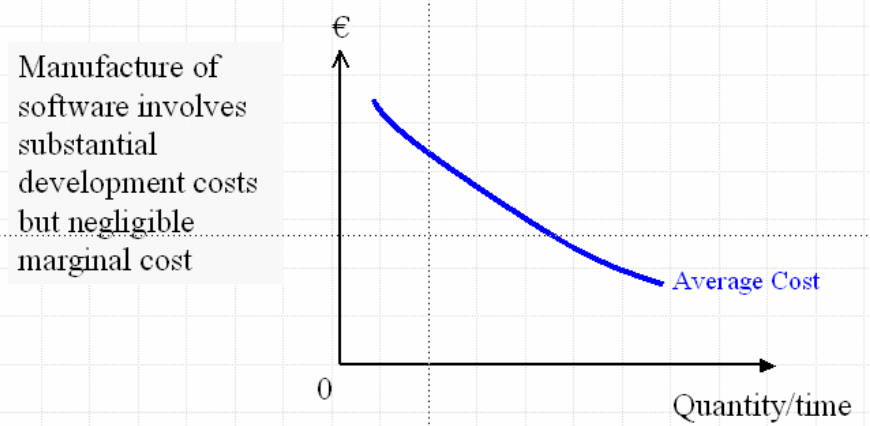

Figure 19: Network Externality and Output

In the graph below, two lines represent the level of consumer benefits or willingness to pay (WTP) with respect to the number of total users. The lower line shows the average willingness to pay without externality. It shifts upward when we consider externality (with more benefits as the number of users increases). The optimal number of product is Q1 at P1 if the firm can charge the benefit from network externality. If not, the output is reduced to Q2 with a lower price P2. At P2, the marginal cost is below the true consumers' willingness to pay, implying that the product is underproduced.

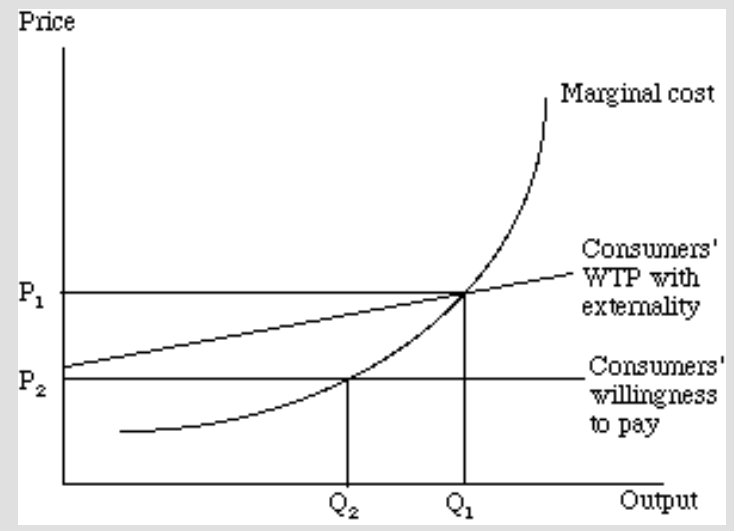




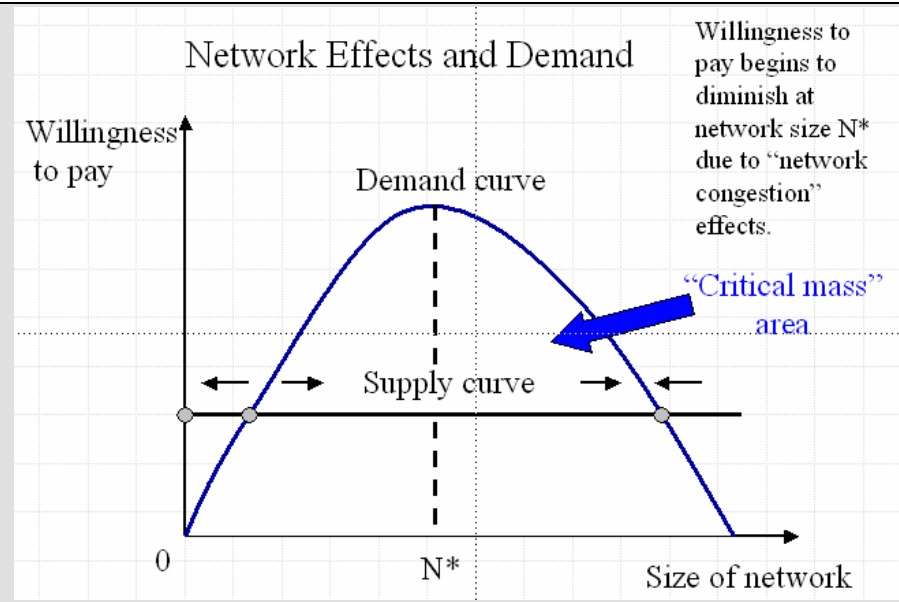

If the firm can operate at (Q1, P1), the market does not have an externality problem. On the other hand, if the firm is forced to operate at (Q2, P2), the market is characterized by a network externality.

Figure 20: Possible market failure

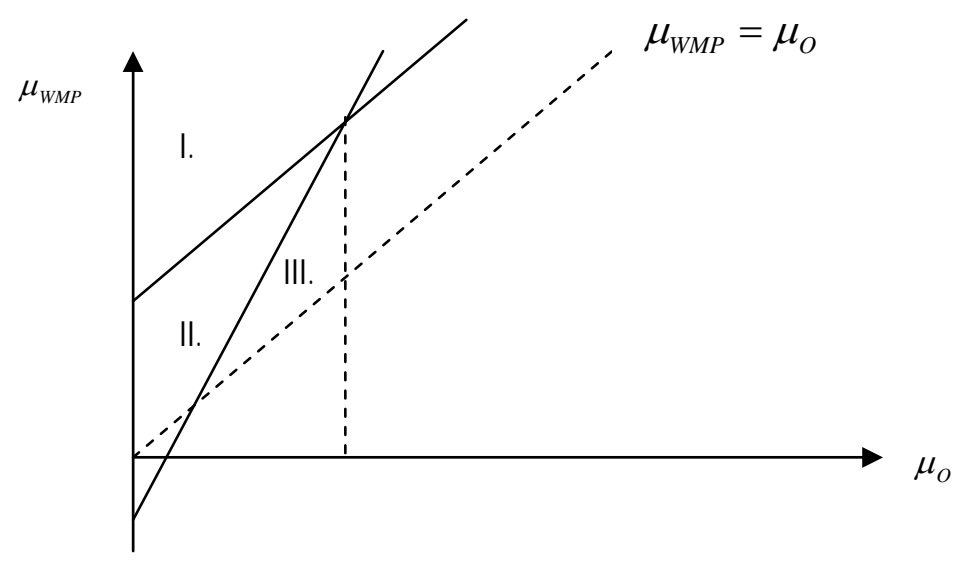

Source: Oz, Shy, The Economics of Network Industries, p.26 


\section{References}

\section{Literature:}

- ARTHER, W.B., [1996] Increasing returns and the new world of business, Harvard Business Review, July-August, 1996, pp. 100-109.

- BAKER, Donald I., Market Definition in Transnational Joint-Ventures, Mergers and Monopolization, p. 118.

- CHOU, C.-F. and SHY, O. [1990], Network effects without network externalities, International Journal of Industrial Organization, 8: 259-270.

- DABBAH, Maher M. [2003], The Internationalization of Antitrust Policy, Cambridge University Press, UK, First published, p. 46-58.

- GOYDER, D G, EC Competition Law, Oxford European Community Law Series, Clarendon Press.

- HANDLER, M., Antitrust in Transition, Volume 2, Transnational Juris Publications Inc. Ardsley-onHudson, New York, p.639.

- KATZ, M.L. and SHAPIRO, C. [1985], Network externalities, competition, and compatibility, American Economic Review, 75(3): 424-440.

- SHY, Oz [2001], The Economics of Networks Industries, Cambridge University Press, USA, p. 2326, $70-72$

- VISCUSI, W. Kip [2001], Economics of Regulations and Antitrust, MIT Press, $3^{\text {rd }}$ Edition, UK, Ch. 4, 6, 7, 9 .

- WALTERS, Stephen J. K. [1993], Enterprise, Government and the public, McGraw Hill, Inc, 1993, p.39.

\section{Articles / Papers:}

- AAI column for FTC: WATCH 3/04 Microsoft and the Media Player Market: There's an American Story, too, Norman Hawker, Western Michigan Universirty: www.antitrustinstitute.org/recent2/304.pdf.

- AYRES, Ian \& NATEBUFF, Barry [2005], Going soft on Microsoft? The EU's Antitrust case and remedy, The Economist's Voice, Vol. 2, Issue 2, Art.4.

- $\quad$ BERGEL, Inga [1997], Effects of globalization on antitrust policy, November $4^{\text {th }}$.

- BROOKER, E., [1998], RealNetworks Exec to Senate: Microsoft Breaks our Software, Internetweek.com, www.internetwk.com/news/news0723-9.htm.

- $\quad$ RIKSDAG, Fran [2001], Nr 30, Almeberg, R, Monti, Foretagen och Konkurrensen, p.3.

- GOLDSMITH, P.I.B., LANZ C. [2001], Maybe Definitely - Definitely Maybe? EC Competition Law - Is the time ripe for Freform?, Eipascope, p. 17

- HEMMingGSSON, Elisabeth [2002], The Volvo/Scania Merger: An Analysis of the EC Merger Process, Gothenburg School of Economics and Commercial Law-Faculty of Law, Masters Thesis in Law, Spring, p.39-40, 42-47. http://www.handels.gu.se/epc/archive/00003259/01/200262.pdf 
- International antitrust co-operation: Bilateralism or Multilateralism?, [2001] Comments of K. von Finckenstein QC, Commissioner of Competition, to the ABA section of Antitrust Laws / CBA National Competition Law Section Conference International antitrust Issues: Pacific Rim and Beyond.

- J. William Rowley QC and Omar K Wakil [2001], Canadian Competition Policy: Preparing the Future, sponsored by the Richard Ivey School of Business, Industry Canada and the Competition Bureau.

- JAMES, Charles A. [2001], International Antitrust in the $21^{\text {st }}$ Century: Cooperation and Convergence, US Department of Justice, Antitrust Division.

- WILKE, John R. \& MITCHENER, Brandon [2003], A Global Journal Report: Microsoft Rivals Allege Antitrust In New EU Case - Group Opens Added Front, Challenging Software Giant Over Windows XP System, Wall St. J.

http://www.global-trade-

law.com/Article.Antitrust\%20(Microsoft\%20\&\%20EU)\%20(WSJ\%202.11.03).htm.

- JONCZEK, Joanna [2004], Competitive Market - Antitrust dimension of competition policy in the EU, YouRec Conference Michal S. Gal, Monopoly pricing as an antitrust offence in the US and EC: Two systems of belief about monopoly?, forthcoming, Antitrust Bulletin.

- LIEBOWITZ, S.J. and S. E. Margolis [1995], Are network externalities a new source of market failure? Research in Law and Economics, 17:1-22.

- KULISH, Nicholas [2002], Nine States Argue That Microsoft Still Illegally Thwarts Competition, all St. J.

- OVERGAARD, Baltzer [2003], Notes on antitrust policy and regulation in the EU and beyond, University of Aarhus.

- Svenska Dagbladet, Ledare [2000], Kommissionen Kvaddar Fusionen, p. 2.

- VAN MIERT, K [1998], The Future of European Competition Policy, Document No: IV/1351/98EN.

- WAKIL, Omar K. [2000], Antitrust Report: Canada and the European Union enter into a new era of antitrust enforcement cooperation, Lexis Publishing.

\section{Other:}

- Case No COMP/M.1672 -Volvo/Scania Regulation (EEC) No 4064/89 Merger Procedure Article 8(3) Date: 15/03/2000 europa.eu.int/comm/competition/ mergers/cases/decisions/m1672_en.pdf

- Commission: DG-Competition: http://europa.eu.int/comm/competition/index_en.html.

- Commission of the European Communities Press Release - 14 March 2000, Press Release Regarding Commission Prohibition of Volvo/Scania Concentration, Document No: EUK9732852.

- VAN GERVEN, Walter [2005], Private enforcement of EC competition rules (provisional background paper), Joint EU Commission/IBA Conference on antitrust reform in Europe: a year in practice, Brussels.

- MONTI, M [2001], Market Definition as a Cornerstone of EU Competition Policy, Speech/01/439, 5 
- OJ, L143, 29/05/2001 P. 0074 - 0132, The Commission Decision, Case No COMP/M. 1672 Volvo/Scania, at paras 13-15

- Revised Recommendation of the OECD Council concerning Cooperation between member countries on Anticompetitive practices affecting international trade, OECD document No C(95)130/Final (Sept. 21, 1995).

- SCHAUB, Alexander [1998], International Co-operation in Antitrust Matters: Making the point in the wake of the Boeing/MDD Proceedings, EC Competition Policy Newsletter, (No. 1), at 2, available at http://europa.eu.int 